\title{
Acidic and Basic Fibroblast Growth Factors Promote Stable Neurite Outgrowth and Neuronal Differentiation in Cultures of PC12 Cells
}

\author{
Russell E. Rydel and Lloyd A. Greene \\ Department of Pharmacology, New York University School of Medicine, New York, New York 10016
}

\begin{abstract}
Acidic (aFGF) and basic (bFGF) fibroblast growth factors are well-characterized peptide hormones that have potent angiogenic activity and that are mitogenic for a variety of cell types. The present findings demonstrate that FGFs can reproduce the entire spectrum of rat pheochromocytoma $\mathrm{PC} 12$ cell responses previously shown to be elicited by NGF. These include responses that are rapid (cell flattening, enhanced phosphorylation of tyrosine hydroxylase) or delayed (neurite outgrowth, induction of phosphorylated MAP1.2, regulation of NILE and Thy-1 glycoproteins, cessation of mitosis, elevation of AChE activity), as well as responses that have been shown to be either transcription-independent (neurite regeneration, promotion of survival) or transcription-dependent (priming, regulation of NILE and Thy-1 glycoproteins, elevation of AChE activity). The only responses for which the FGFs and NGF consistently showed quantitative differences were in the rates for neurite initiation and elongation in serum-containing medium. Thus, while all 3 factors promoted the formation of stable neurites, the network of outgrowth elicited by NGF at any given time of treatment was always of greater density. Togari et al. (1985) have previously reported that bFGF can initiate transient neurite formation in PC12 cell cultures. The present observations describe a variety of additional actions of bFGF on a neuronal cell line, and demonstrate that aFGF is capable of mimicking many, if not all, of these actions. These observations thus extend the range of actions that aFGF and bFGF may potentially exert on nerve cells, either during their development, repair, or maintenance. In addition, this work suggests that the PC12 cell line may serve as a useful model system with which to study the mechanism of action of FGFs on neurons. Since all 3 factors appear capable of eliciting the same wide spectrum of responses, molecular events specifically associated with FGFs and NGF in PC12 cells may prove illuminating of the causal steps involved in neuronal differentiation.
\end{abstract}

\footnotetext{
Received Oct. 27, 1986; revised Mar. 12, 1987; accepted May 5, 1987.

We gratefully acknowledge the generous gifts of bovine acidic and basic FGFs from Dr. D. Gospodarowicz, and human basic FGF from Dr. D. B. Rifkin. We also thank Dr. S. H. Green for his valuable comments on the manuscript. This work was supported by NIH Research Grant NS 16036 to L.A.G. R.E.R. was supported in part by NIH Predoctoral Training Grant GM 07827 and L.A.G. was a Career Development Awardee of the Irma T. Hirschl Trust.

Correspondence should be addressed to Dr. Lloyd A. Greene, Department of Pharmacology, New York University Medical Center, 550 First Avenue, New York, NY 10016.
}

Copyright $(\mathcal{C} 1987$ Society for Neuroscience $0270-6474 / 87 / 113639-15 \$ 02.00 / 0$
Cell-cell interactions profoundly influence the survival and differentiation of the developing nervous system. Trophic molecules represent an attractive mechanism for mediating influences of this type (reviewed in Berg, 1984). A role for neurotrophic molecules during development is most clearly demonstrated by the example of the peptide hormone NGF, which plays a critical role in the development of the sympathetic and sensory nervous systems (for reviews, see Greene and Shooter, 1980; Vinores and Guroff, 1980; Yankner and Shooter, 1982), and which also appears to affect certain CNS neurons (reviewed in Korsching, 1986). NGF's primary actions on target cells, including maintenance of survival, induction of neurite outgrowth, and alterations in the metabolism of neurotransmitters, are reproducible in vitro, thus allowing questions of neuronal development to be addressed by cell culture techniques. One target of NGF, the rat $\mathrm{PC} 12$ pheochromocytoma cell line, has proved to be useful for studying NGF's mechanism of action (Greene and Tischler, 1982). PC1 2 cells resemble adrenal medullary chromaffin cells, but when exposed to NGF for several days, they cease cell division and undergo conversion to a sympathetic neuron-like phenotype (Greene and Tischler, 1976). Both transcription-independent and transcription-dependent pathways appear to be involved in the NGF-induced neuronal differentiation of $\mathrm{PC} 12$ cells (reviewed in Greene, 1984), though current knowledge of the molecular events orchestrating this neuronal conversion is still limited.

In order to more fully understand the molecular events underlying NGF-induced neuronal differentiation, we have begun to tcst various agents for their capacities to mimic some, or all, of NGF's responses in PC12 cells. This approach should allow the identification of molecular events associated with particular responses in PC1 2 cells and, therefore, permit more precise dissection of the various pathways that comprise the NGF response. Furthermore, agents found to mimic most, if not all, of NGF's actions on PC12 cells should be potentially strong candidates for a neurotrophic role in nervous system development.

Among the potentially interesting agents to be tested in the PC1 2 cell system are the fibroblast growth factors (FGFs). Acidic FGF (aFGF) and basic FGF (bFGF) are well-characterized peptide hormones that have potent angiogenic activity and are mitogenic for a variety of cell types (for reviews, see Gospodarowicz et al., 1986; Lobb et al., 1986; Thomas and GimenezGallego, 1986). aFGF shares a $55 \%$ sequence homology with bFGF (Esch et al., 1985b; Gimenez-Gallego et al., 1985), and both forms appear to promote their biological effects via interaction with the same specific cell-surface receptor sites (Neufeld and Gospodarowicz, 1986). Walicke et al. (1986) and Morrison et al. (1986) have recently reported that bFGF enhances both 
the survival and extent of neurite outgrowth in cultures of dissociated hippocampal neurons and cerebral cortical neurons, respectively. This, coupled with the finding that neural tissue is a rich source of both aFGF (Lobb and Fett, 1984; Thomas et al., 1984) and bFGF (Gospodarowicz et al., 1984), raises the possibility that FGFs may play a role in normal nervous system development or function.

Of particular relevance and interest here are the reports of Togari et al. $(1983,1985)$ that bFGF can mimic some, but not all, of NGF's actions on PC12 cells. Basic FGF was reported to induce transient process outgrowth and ornithine decarboxylase activity, but, in contrast to NGF, did not increase AChE activity and was unable to promote "priming" (discussed below) in PC12 cell cultures. On this basis, it was suggested that bFGF may have effects on PC12 cells similar to those promoted by permeant analogs of cAMP. Such analogs mimic some of the early responses of PC 12 cells to NGF, but do not mimic most of the delayed, transcription-dependent actions of this growth factor (reviewed in Greene and Shooter, 1980).

In this study, we tested both $\mathrm{aFGF}$ and bFGF for their ability to promote both early and delayed responses of PC12 cells, and compared their responses with those elicited by NGF. The following responses were examined: cell morphology and neurite outgrowth, priming, survival and neurite outgrowth in serumfree medium, cell division rate, short- and long-term effects on specific phosphoproteins, synthesis of specific glycoproteins, and AChE activity. These included transcription-independent and transcription-dependent responses, ranging in appearance from minutes to days. We report that $\mathrm{aFGF}$ and $\mathrm{bFGF}$ mimic all NGF responses tested in PC12 cells. Both aFGF and bFGF produced stable neuritc outgrowth and ncuronal differentiation in $\mathrm{PC} 12$ cell cultures. These findings support a neurotrophic role for FGFs in nervous system development and indicate that PC1 2 cells may serve as a model system to study the mechanism of this action of FGFs.

Some of the results reported here have previously appeared in abstract form (Rydel and Greene, 1985).

\section{Materials and Methods}

Cell culture methods. $\mathrm{PCl} 2$ cells were cultured as previously described (Greene and Tischler, 1976). For most experiments, cells were mechanically dislodged for passaging by forceful aspiration of medium through a pasteur pipette and plated into $35 \mathrm{~mm}$ collagen-coated tissue culture dishes containing a total of $1.5 \mathrm{ml}$ of complete medium. For determination of survival in serum-free medium, cultures of PC1 2 cells were washed 3 times with serum-free medium [Roswell Park Memorial Institute Medium 1640 (RPMI 1640) containing antibiotics but no additional additives] and then maintained with serum-free medium containing either FGF or NGF. All cultures were maintained in an atmosphere of $93 \%$ air, $7 \% \mathrm{CO}_{2}$ at $37^{\circ} \mathrm{C}$. The medium of stock cultures was exchanged 3 times/week, while experimental cultures, unless otherwise specified, were treated every other day.

Measurements of cellular responses to FGFs and NGF. Cell counts were determined by removing the culture medium and dissolving the cells in a detergent lysing solution, as described by Soto and Sonnenschein (1985), and then counting the nuclei using a hemacytometer. For each treatment, at least 1000 cells were counted. The proportion of neurite-bearing cells was determined by counting the number of cells containing processes at least twice the length of the cell body (i.e., $\geq 20$ $\mu \mathrm{m}$ in length). For each treatment, at least 300 randomly selected cells were scored. Neurite lengths were determined by the use of an eyepiece micrometer. At least 30-50 random neurites were measured for each treatment; lengths are reported as means \pm SEM.

Cultures used for isolation of Triton X-100-soluble phosphoproteins were plated at a density of $1 \times 10^{5} \mathrm{cells} / \mathrm{cm}^{2}$. Prior to labeling, each culture was washed 3 times with 2 mI RPMI 1640 (without added serum) and maintained under these conditions for $12 \mathrm{hr}$. This procedure greatly eliminated background, serum-induced phosphorylations without compromising PC12 cell viability. Labeling with ${ }^{32} \mathrm{P}$-orthophosphate was performed as described by Seeley et al. (1984). At the end of the incubation, cultures were rinsed twice with PBS, extracted for $10 \mathrm{~min}$ with a microtubule-stabilizing buffer, modified from Solomon et al (1979), containing $0.1 \%$ Triton X-100 (10 mm imidazole, $\mathrm{pH} 7.2-7.35$, $1 \mathrm{~mm} \mathrm{MgCl}, 75 \mathrm{~mm} \mathrm{KCl}, 50 \mathrm{~mm} \mathrm{NaF}, 2 \mathrm{~m}$ glycerol, $1 \mathrm{~mm}$ EGTA, $0.1 \%$ Triton X-100, $2 \mathrm{~mm}$ phenylmethylsulfonyl fluoride, and $100 \mathrm{kal}-$ likrein-inhibition $\mathrm{U} / \mathrm{ml}$ aprotinin). To $800 \mu \mathrm{l}$ of the solubilized proteins in the Triton/glycerol extract was added $267 \mu \mathrm{l}$ of $4 \times$ sample buffer (Laemmli, 1970). Samples were incubated in a boiling-water bath for $5 \mathrm{~min}$. Proteins were subsequently resolved on $32 \mathrm{~cm}, 5-10 \%$ linear gradient SDS polyacrylamide gels, using the protocol of Greene et al. (1983). The gels were dried and autoradingrams were prepared using Kodak XAR-5 x-ray film. Quantification was carried out over an approximately linear range of film density using a Hoefer Scientific GS 300 scanning densitometer, and individual peaks integrated to determine relative peak areas using the SCANGEL program, written by S. A. Drexler (Department of Pharmacology, New York University School of Medicine).

Previously published procedures were used for all of the remaining analyses performed in this study. ${ }^{32} \mathrm{P}$-orthophosphate-labeled proteins from cultures treated for $13 \mathrm{~d}$ with either bFGF or NGF in the presence of $1 \%$ horse serum or PC12 cell-conditioned medium (see below) were resolved by methods described in Greene et al. (1983), except that gel electrophoresis was performed using gels containing $4 \mathrm{M}$ urea and $3.2 \%$ polyacrylamide, or $32 \mathrm{~cm}, 7.5-15 \%$ linear gradient gels. ${ }^{3} \mathrm{H}$-fucose-labeled proteins were identified by methods described in Richter-Landsberg et al. (1985). AChE activity and protein determinations were measured as described in Greene and Rukenstein (1981) and are reported as means $\pm \mathrm{SD}$

Materials. Mouse 2.5 S NGF was prepared from adult male submandibular glands according to the method of Mobley et al. (1976). NGF concentration was determined spectrophotometrically, assuming $A_{0.1 \%}^{280}=1.6$, and activity was assessed by means of a quantitative bioassay (Greene, 1977). NGF was estimated to be greater than $99 \%$ pure, based on silver-stained, SDS-polyacrylamide electrophoretic gels. When employed, NGF was used at a saturating concentration of $50 \mathrm{ng} / \mathrm{ml}$. Acidic and basic FGFs, prepared from bovine brain (Bohlen et al., 1985) and pituitary (Gospodarowicz et al., 1984), respectively, were generously supplied by Dr. D. Gospodarowicz (Cancer Research Institute, University of California Medical Center, San Francisco). The homogeneity of each was confirmed by SDS-PAGE, amino acid composition and amino-terminus sequencing. Human basic FGF was generously supplied by Drs. D. B. Rifkin and D. M. Moscatelli (Department of Cell Biology, New York University Medical Center) and was isolated from term human placenta by a modification of a procedure described previously (Moscatelli et al., 1986). After clution from heparin-Sepharose, the active fractions were dialyzed against $0.2 \mathrm{M} \mathrm{NaCl}, 20 \mathrm{~mm} 2-(N$-morpholino)ethanesulfonic acid (MES), $\mathrm{pH} \mathrm{6.0,} \mathrm{clarified} \mathrm{by} \mathrm{centrifugation}$ at $100,000 \times g$ for $60 \mathrm{~min}$, and loaded onto a FPLC-Mono S column (Pharmacia) equilibrated with the same buffer. Basic FGF was eluted with a gradient of $0.2-0.7 \mathrm{M} \mathrm{NaCl}$ in $20 \mathrm{~mm}$ MES, pH 6.0 , and silverstained as a single band $\left(M_{\mathrm{r}} \simeq 18.7 \mathrm{kDa}\right)$ under both reducing and nonreducing conditions after SDS-PAGE. Its identity was based upon its affinity for heparin-Sepharose, cross-reactivity with antibodies to basic FGF (Moscatelli et al., 1986), and amino acid sequence data (Sommer et al., 1987). Antiserum to NGF was prepared in a rabbit, as described by Zanini et al. (1968), and was generously supplied by Drs. C. Keith and M. Shelanski (Department of Pharmacology, New York University Medical Center); it was used at a dilution (1:100) that fully blocked the ncurite outgrowth-promoting effects of $50 \mathrm{ng} / \mathrm{ml} \mathrm{NGF}$ on PC12 cell cultures.

PC1 2 cell-conditioned medium (CM) was obtained from high-density $\left(\sim 10^{6}\right.$ cells $\left./ \mathrm{cm}^{2}\right)$ cultures of untreated PC1 2 cells. Medium obtained in the process of feeding stock cultures was pooled and filtered through a $0.45 \mu \mathrm{m}$ filter to remove particulate matter, then frozen at $-20^{\circ} \mathrm{C}$ for later use. $\mathrm{CM}$ was mixed with fresh complete medium before use to obtain a final concentration of $70 \% \mathrm{CM}$. CM alone produced no demonstrable effects on $\mathrm{PC} 12$ cells.

Actinomycin D (Sigma) was diluted into medium from a stock solution $(400 \mu \mathrm{M})$ dissolved in $50 \%$ propylene glycol; the carrier alone, when added to control cultures, had no demonstrable effects. The sodium salt of heparin (Sigma) was diluted into medium from a stock 

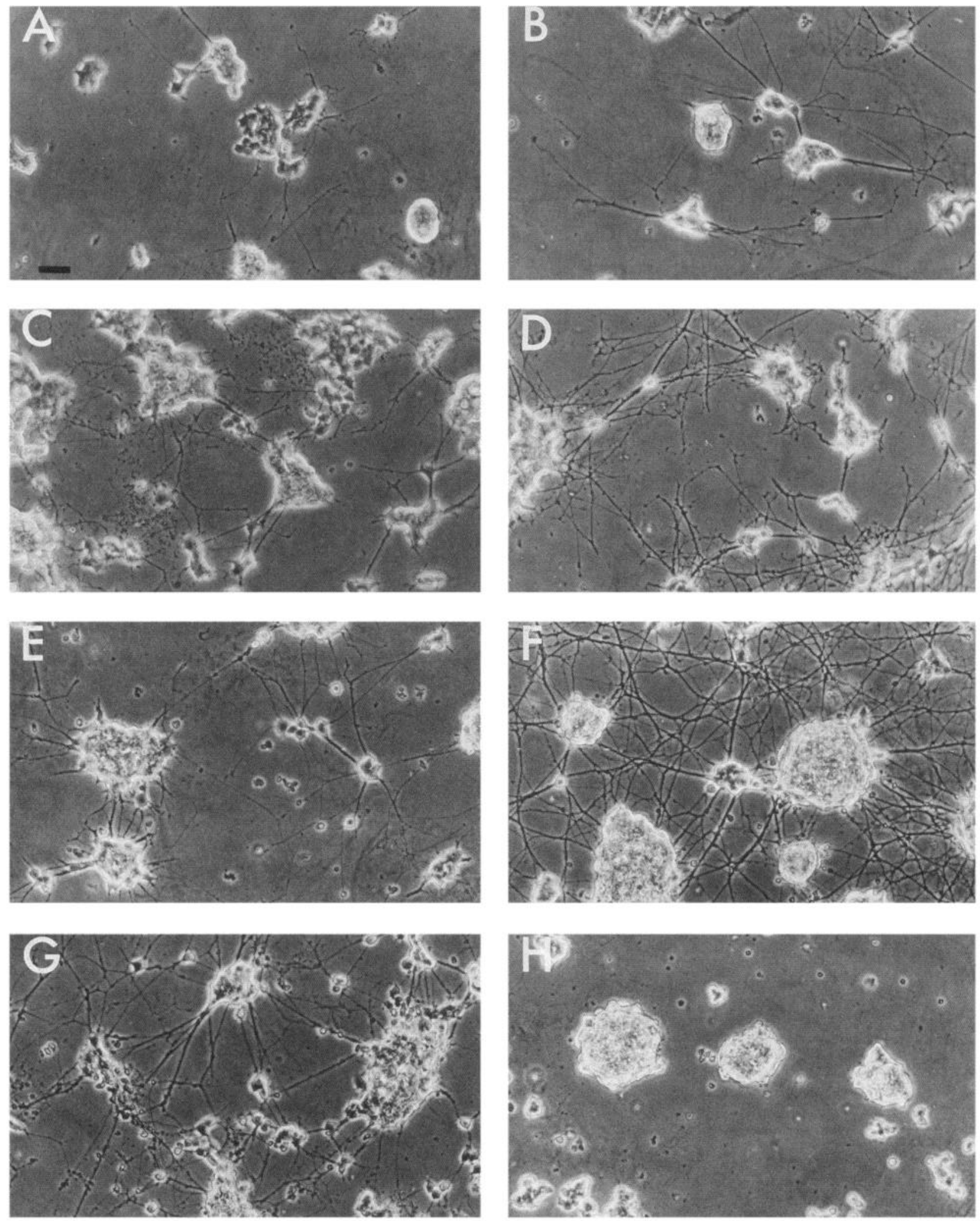

Figure 1. Stable neurite outgrowth by $\mathrm{PC} 12$ cells following treatment with $\mathrm{bFGF}$ or NGF in serum-containing medium. Cells $\left(3.8 \times 10^{4} / \mathrm{cm}^{2}\right)$ were on collagen-coated dishes and in the presence of various treatments, as follows: $A, 5 \mathrm{ng} / \mathrm{ml}$ bovine bFGF for $6 \mathrm{~d} ; B, 50 \mathrm{ng} / \mathrm{ml} \mathrm{NGF}$ for $6 \mathrm{~d}$; $C, 5 \mathrm{ng} / \mathrm{ml}$ bovine bFGF in the presence of conditioned medium (CM) for $6 \mathrm{~d} ; D, 50 \mathrm{ng} / \mathrm{ml} \mathrm{NGF}$ in the presence of CM for $6 \mathrm{~d} ; E, 5 \mathrm{ng} / \mathrm{ml}$ bovine bFGF for $12 \mathrm{~d} ; F, 50 \mathrm{ng} / \mathrm{ml} \mathrm{NGF}$ for $12 \mathrm{~d} ; G, 50 \mathrm{ng} / \mathrm{ml}$ human bFGF for $17 \mathrm{~d} ; H$, no addition. Bar, $50 \mu \mathrm{m}$. 
Figure 2. Time courses for the appearance of neurites and for neurite elongation in cultures of $\mathrm{PC} 12$ cells following treatment with $\mathrm{bFGF}$ or NGF. Cultures $\left(10^{4} / \mathrm{cm}^{2}\right)$ were maintained with complete growth medium and scored at various times for both the percentage of neurite-bearing cells (upper panel) and neurite length (lower panel) in the presence of either $5 \mathrm{ng} / \mathrm{ml}$ bovine bFGF $(x)$ or $50 \mathrm{ng} / \mathrm{ml} \mathrm{NGF}(O)$. For neurite lengths, vertical bars show SEM for measurements on 30-50 neurites.

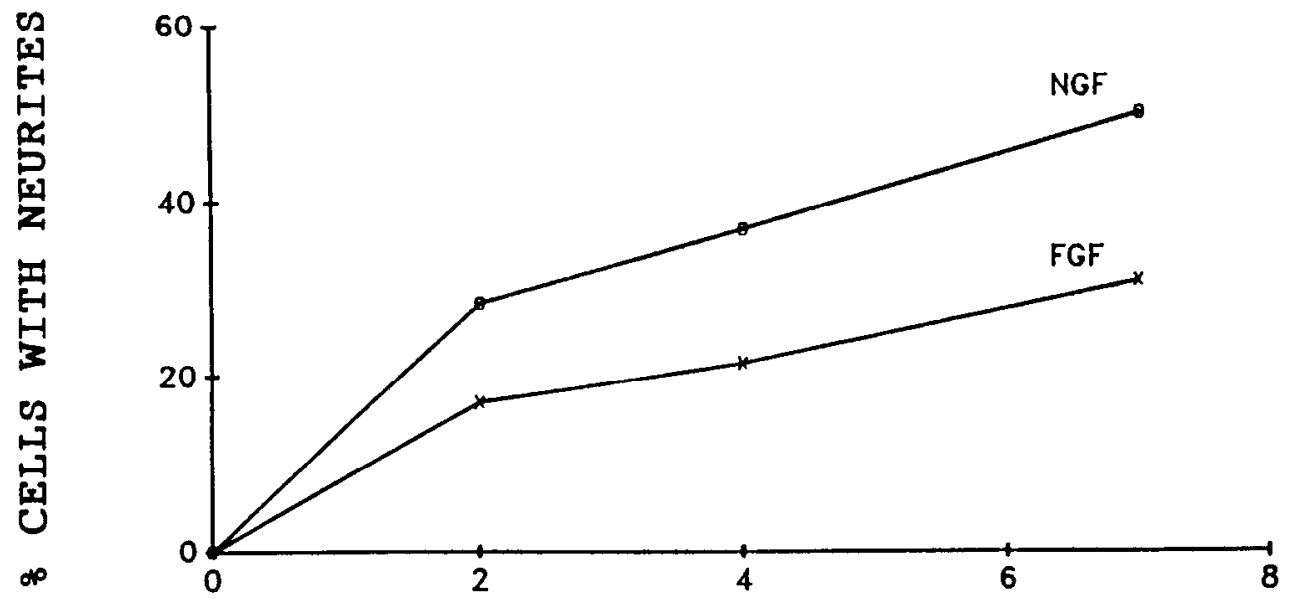

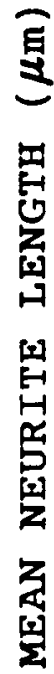

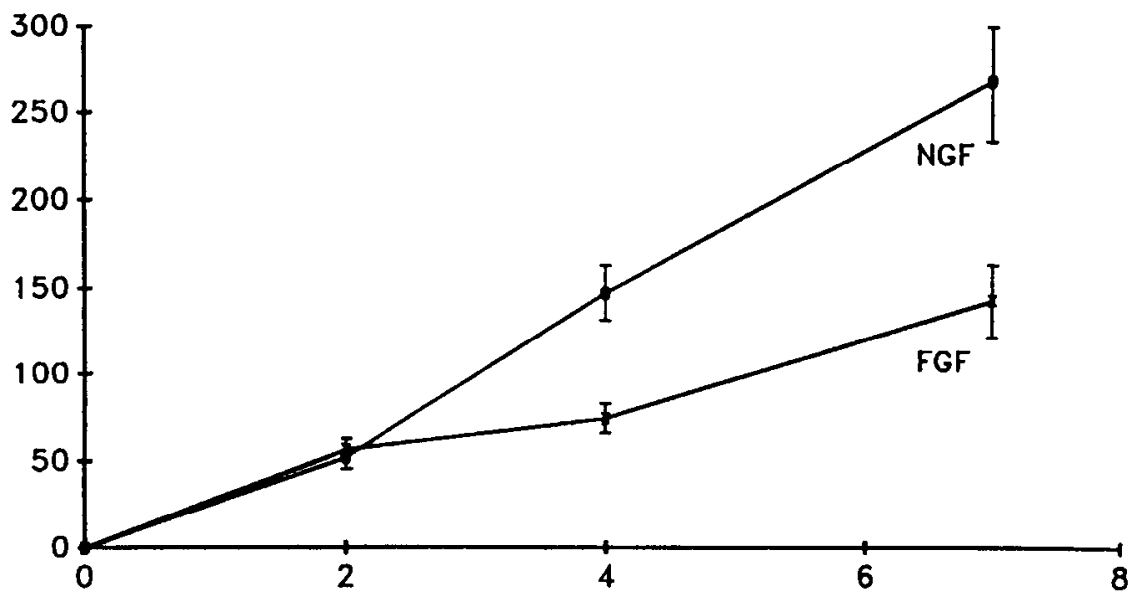

DAYS OF TREATMENT solution $(500 \mu \mathrm{g} / \mathrm{ml})$ dissolved in RPMI 1640 . Materials for polyacrylamide gels were purchased from Bio-Rad.

\section{Results}

\section{Morphology and neurite outgrowth}

Basic FGF. The morphological responses of PC1 2 cells to treatment with bFGF are almost qualitatively identical to those seen with NGF. Both bFGF and NGF induce cell flattening and the production of short, cytoplasmic extensions (spiking) within minutes to hours following their addition to cultures. Neurites are first detectable with either treatment after a lag period of about $1 \mathrm{~d}$, and continue to appear over a time course of many days (Figs. $1, A, B, E, F ; 2$ ). Such neurites are easily distinguishable from cytoplasmic spikes in that they possess branches and flattened growth-cone-like structures, and elongate beyond 2 cell body diameters. Togari et al. (1985) have previously shown that bFGF elicits neurite formation by $\mathrm{PC} 12$ cells, but reported that the processes that formed were relatively short and retracted within 3-6 d of treatment. We have followed cultures of PC12 cells treated with bFGF for up to $30 \mathrm{~d}$ and found no evidence of deterioration or retraction of neuritic processes. These stable neurites may reach lengths of several hundred micrometers (cf. Fig. 1, $E, G)$. Furthermore, anti-NGF antiserum had no effect on FGF-induced outgrowth (data not shown).

Initiation of neurite outgrowth was tested at bovine bFGF concentrations ranging from 0.2 to $135 \mathrm{ng} / \mathrm{ml}$, with maximal outgrowth occurring at $5-15 \mathrm{ng} / \mathrm{ml}$ (300-900 pM). Cell flattening and spiking were evident at all concentrations used, though, by visual inspection, neurite outgrowth was greatly diminished or absent at doses of less than $1 \mathrm{ng} / \mathrm{ml}$ or greater than $100 \mathrm{ng} / \mathrm{ml}$. Additional studies (see below) on both bovine bFGF-induced neurite regeneration from primed $\mathrm{PC} 12$ cells and survival of $\mathrm{PC} 12$ cells in serum-free medium resulted in similar dose-response relationships.

The source of bFGF does not appear to alter the response of PC1 2 cells. Human placental bFGF produces stable neurite outgrowth identical to that produced by bovine pituitary bFGF (Fig. $1 G$ ). However, the potency of human bFGF differed from that of bovine bFGF. Dose-response experiments $(0.6-150 \mathrm{ng} /$ $\mathrm{ml}$ ) revealed some effect of human bFGF on neurite formation at $5 \mathrm{ng} / \mathrm{ml}(300 \mathrm{pM})$, while maximal neurite outgrowth occurred at $50 \mathrm{ng} / \mathrm{ml} \mathrm{(3} \mathrm{nM;} \mathrm{Fig.} 1 G)$ and above. Human bFGF-induced neurite regeneration from primed PC12 cells, and survival of 


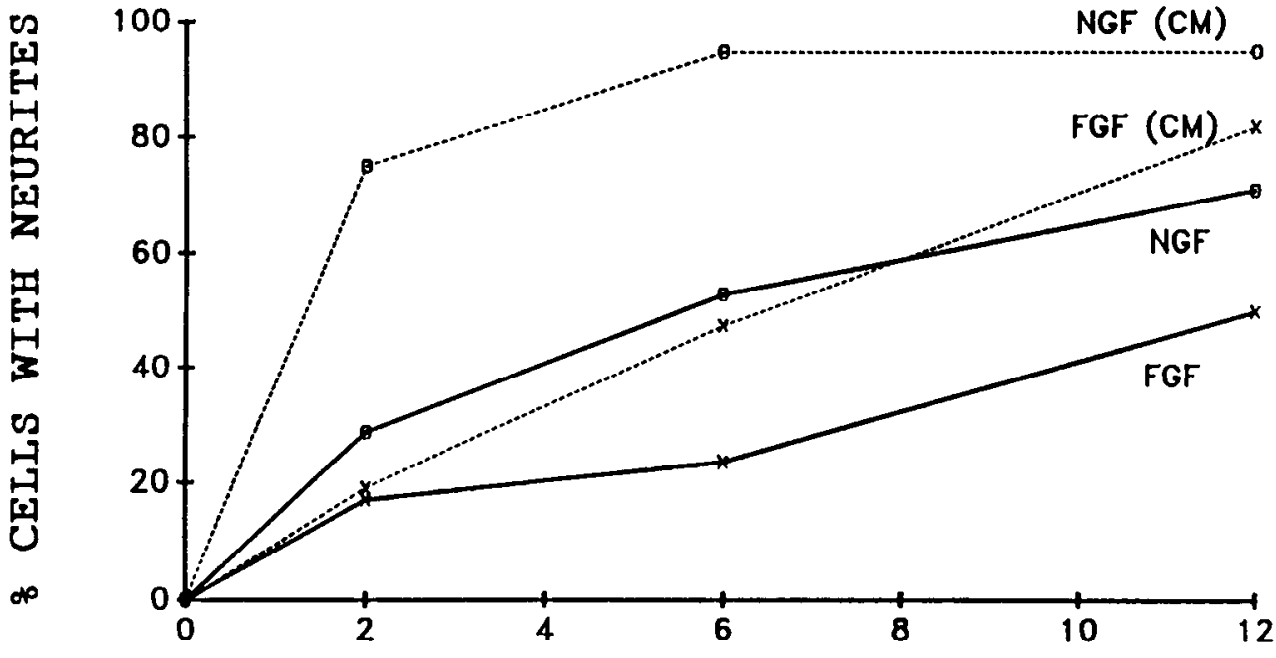

DAYS OF TREATMENT
Figure 3. Effect of conditioned medium on the rate of neurite initiation by $\mathrm{PC} 12$ cells in the presence of bFGF or NGF. Cultures of $\mathrm{PC} 12$ cells $\left(10^{4} /\right.$ $\mathrm{cm}^{2}$ ) were scored at various times for the percentage of neurite-bearing cells in the presence of complete growth medium (solid lines) or conditioned medium (dashed lines) and either $50 \mathrm{ng} /$ $\mathrm{ml} \mathrm{NGF}(\mathrm{O})$ or $5 \mathrm{ng} / \mathrm{ml}$ bovine bFGF $(x)$. For each treatment, at least 300 random cells were scored.
PC12 cells in serum-free medium (see below) also follow a similar dose-response relationship. Recent protein sequencing of the human bFGF used in this study (Sommer et al., 1987) has determined that it possesses an 11-amino acid extension at the amino terminus that is not present in the bovine bFGF we employed (Esch et al., 1985a), and 2 amino acid substitutions relative to bovine bFGF. These differences in protein structure between human and bovine bFGF may account for the differences in their relative potencies.

One difference found between NGF and bFGF is that bFGF addition in serum-containing medium always resulted in a neuritic network of lesser density than that produced by comparable NGF treatment. This difference in the density of neurites was first evident after $2 \mathrm{~d}$ of treatment, and was clearly obvious after $6 \mathrm{~d}$ of treatment (Fig. $1, A, B$ ). In addition, analyses of the rates for neurite initiation and neurite elongation revealed that both are less with bFGF as compared to NGF treatment (Fig. 2). At every time point tested, PC12 cultures treated with bFGF displayed fewer cells possessing neurites than did cultures treated with NGF (Fig. 2, upper panel). Neurite elongation after bFGF addition followed a near-linear mean rate of $18 \mu \mathrm{m} / \mathrm{d}(R=0.98)$, as compared to a near-linear mean rate of $43 \mu \mathrm{m} / \mathrm{d}(R=0.99)$ with NGF treatment (Fig. 2, lower panel). The latter value is in close agreement with a mean elongation rate of $42 \mu \mathrm{m} / \mathrm{d}$ previously reported for NGF treatment of PC12 cells (Greene et al., 1982). One possible explanation for these differences between bFGF and NGF could be a reduced stability or more rapid degradation of bFGF in the culture medium; bFGF has an in vitro half-life of $\sim 24 \mathrm{hr}$ at $37^{\circ} \mathrm{C}$ (Westall et al., 1983). However, treatment of PC12 cells with human bFGF every 12 hr instead of every 2 d over a period of 1 week did not alter the pattern or density of neurite outgrowth (data not shown).

Our initial experiments were performed with cells at a low density of $1 \times 10^{4}$ cells $/ \mathrm{cm}^{2}$. In these cultures, not only were the lengths and density of neurites produced in the presence of bFGF diminished as compared to those generated in the presence of NGF, but there was also a considerable difference in the proportion of cells that displayed neurites, even after $12 \mathrm{~d}$ of treatmont (Fig. 3). Under these conditions, about $70 \%$ of PC12 cells possessed neurites after 1-2 weeks of NGF treatment, yet
bFGF treatment for $12 \mathrm{~d}$ resulted in neurite formation by only $50 \%$ of the cells. Increasing the cell density 5-fold (from $1 \times$ $10^{4}$ to $5 \times 10^{4}$ cells $/ \mathrm{cm}^{2}$ ) significantly augmented the percentage of cells possessing neurites after $12 \mathrm{~d}$ of treatment with either bFGF $(50 \%$ to $>95 \%)$ or NGF $(71 \%$ to $>95 \%)$.

These effects of increased cell density could be mimicked with medium conditioned by high-density cultures of NGF-untreated PC1 2 cells (CM). This material was found to significantly potentiate the formation of neurites elicited by either bFGF or NGF in low-density cultures (compare Fig. $1, A, B$ with $C, D$; Fig. 3). The use of $C M$ with these low-density cultures resulted in $>80 \%$ of the cells generating neurites after $12 \mathrm{~d}$ of exposure to bFGF (Fig. 3). Treatment with CM alone, without added growth factors, produced no changes in cell morphology (data not shown). The above findings indicate that all, or nearly all, PC12 cells are capable of responding to bFGF. Furthermore, as shown in Figure 3, serum and conditioning factors appear to more greatly potentiate the effects of NGF on neurite formation than they do for the effects of bFGF treatment.

Acidic FGF. Bovine aFGF was also tested for its effects on PC1 2 cell morphology. Treatment of PC12 cell cultures with aFGF at concentrations of up to $50-150 \mathrm{ng} / \mathrm{ml} \mathrm{(3-9} \mathrm{nM})$ resulted mainly in cell flattening and spiking, with minimal neurite outgrowth after 1 week of exposure (Fig. $4 B$ ). This is consistent with the finding (Bohlen et al., 1985; Esch et al., 1985a) that the mitogenic and angiogenic activities of aFGF are 30-100fold less potent than those of bFGF. It has also been reported that aFGF binds to heparin, and that the presence of heparin appears to both stabilize the active conformation of aFGF and decrease the apparent $K_{\mathrm{d}}$ of binding to its receptor, thereby potentiating the effects of aFGF (Schreiber et al., 1985). Basic FGF also binds to heparin, but, in contrast, is not potentiated by this material (Lobb et al., 1986; Thomas and Gimenez-Gallego, 1986). In the present experiments, heparin was found to significantly affect the neurite-promoting activity of aFGF. Concentrations of a FGF as low as $5 \mathrm{ng} / \mathrm{ml}(300 \mathrm{pM})$ resulted in significant neurite outgrowth when added in the presence of 50 $\mu \mathrm{g} / \mathrm{ml}$ heparin (Fig. $4 A$ ). As in the case of bFGF, these neurites were stable for at least several weeks. Also, as shown in Figure 4 , the presence of heparin neither potentiates nor inhibits the 

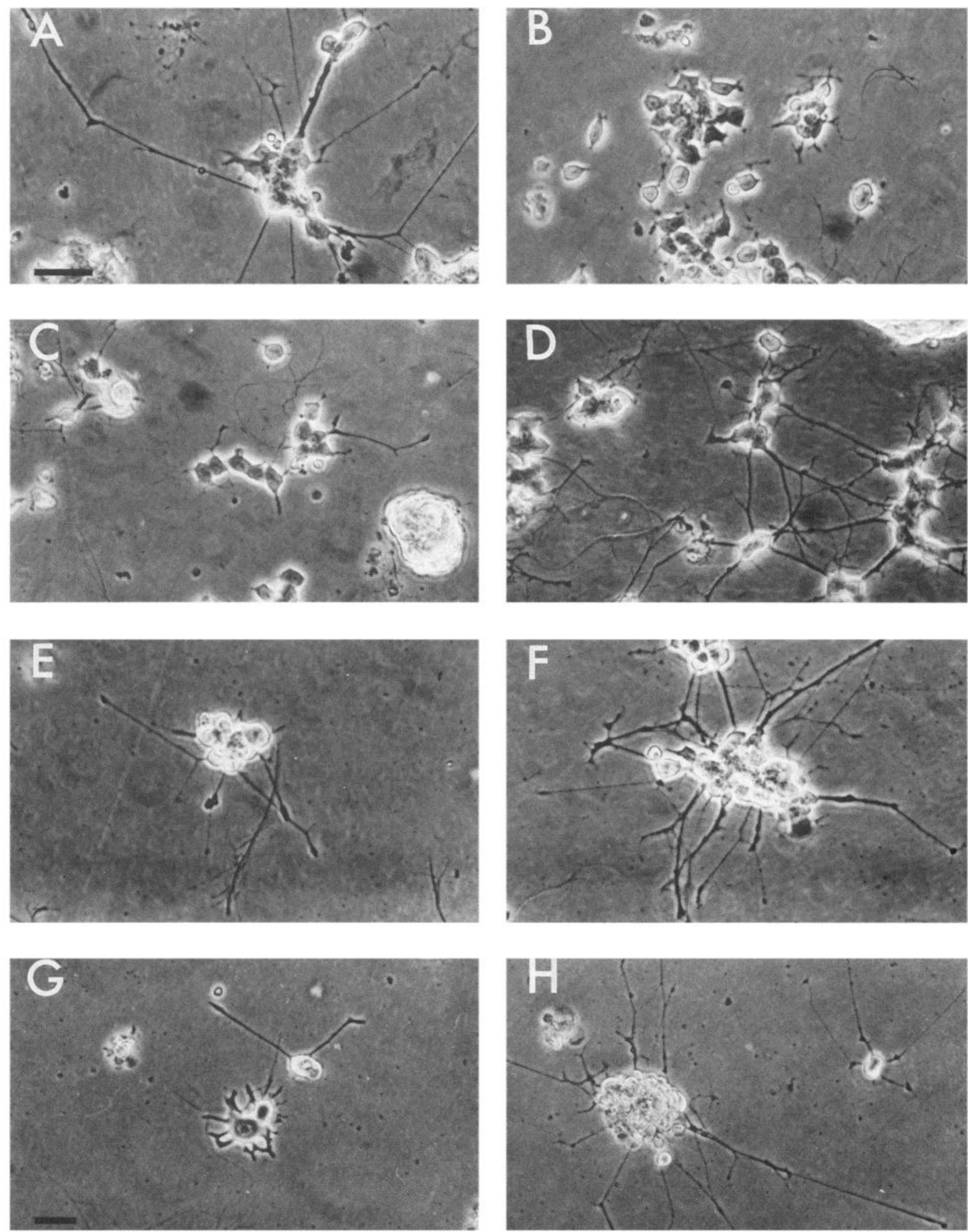

Figure 4. Phase-contrast micrographs of PC12 cells maintained in complete medium under the following conditions: $A, 5 \mathrm{ng} / \mathrm{ml}$ bovine aFGF in the presence of $50 \mu \mathrm{g} / \mathrm{ml}$ heparin for $7 \mathrm{~d} ; B, 50 \mathrm{ng} / \mathrm{ml}$ bovine aFGF alone for $7 \mathrm{~d} ; C, 5 \mathrm{ng} / \mathrm{ml}$ human bFGF in the presence of $50 \mu \mathrm{g} / \mathrm{ml}$ heparin for $7 \mathrm{~d} ; D, 50 \mathrm{ng} / \mathrm{ml}$ human bFGF alone for $7 \mathrm{~d} ; E, 50 \mathrm{ng} / \mathrm{ml} \mathrm{NGF}$ for $14 \mathrm{~d}$, triturated to shear off neurites, and replated for $1 \mathrm{~d}$ in the presence of $50 \mathrm{ng} / \mathrm{ml}$ human bFGF and $10 \mu \mathrm{M}$ actinomycin D; $F$, as in $E$, but replated for $1 \mathrm{~d}$ in the presence of $50 \mathrm{ng} / \mathrm{ml} \mathrm{NGF}$ and $10 \mu \mathrm{M}$ actinomycin D; $G, 50 \mathrm{ng} / \mathrm{ml}$ human bFGF for $14 \mathrm{~d}$, triturated to shear off neurites, and replated for $1 \mathrm{~d}$ in the presence of $50 \mathrm{ng} / \mathrm{ml}$ human bFGF and $10 \mu \mathrm{M}$ actinomycin $\mathrm{D} ; H$, as in $G$, but replated for $1 \mathrm{~d}$ in the presence of $50 \mathrm{ng} / \mathrm{ml} \mathrm{NGF}$ and $10 \mu \mathrm{M}$ actinomycin D. Bar, $50 \mu \mathrm{m}$. 


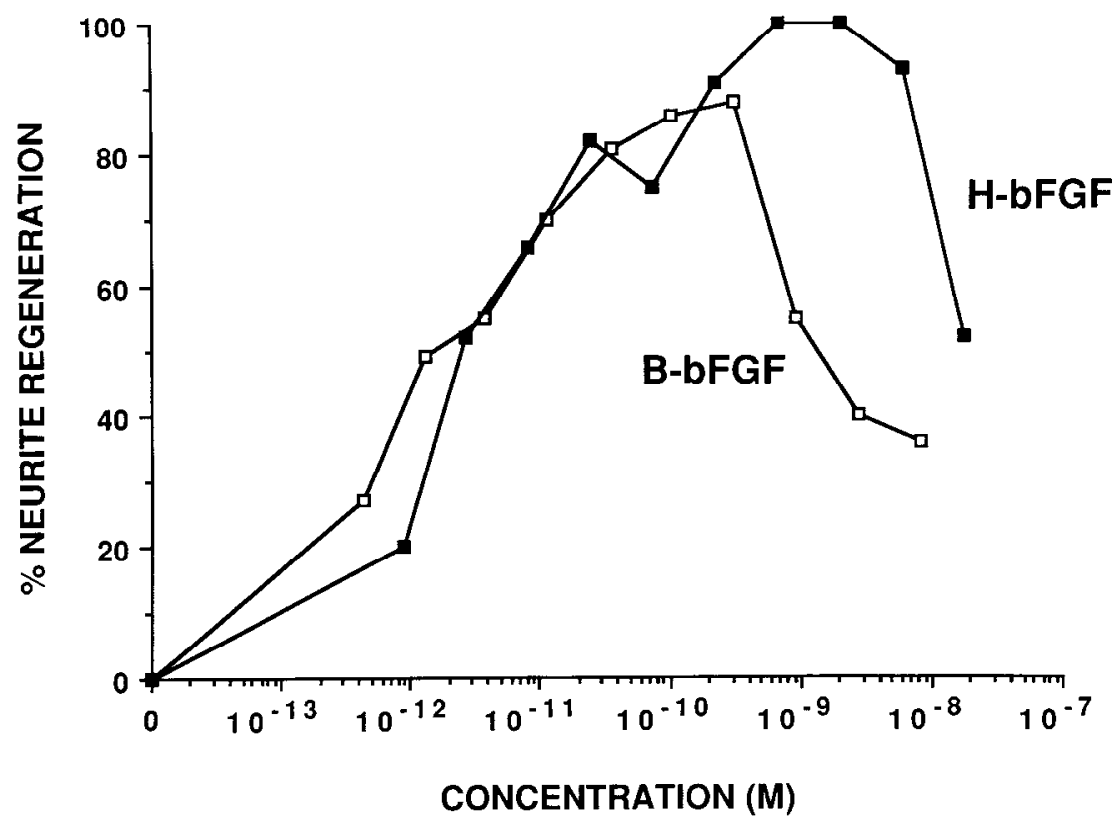

Figure 5. Dose-response relationship for the effects of bovine and human bFGF on neurite regeneration by $\mathrm{PC} 12$ cells. PC12 cultures were maintained for $14 \mathrm{~d}$ with $50 \mathrm{ng} / \mathrm{ml} \mathrm{NGF}$, triturated to shear off neurites, and replated in the absence of NGF and in complete medium in the presence of varying concentrations of bovine (B) bFGF (open boxes) or human (H) bFGF (filled boxes). Approximately $24 \mathrm{hr}$ after replating, the cultures were scored for proportion of neurite-bearing cells. At least 100 randomly selected cell clumps were scored per point. For each point, the data were normalized so that $100 \%$ neurite regeneration equals the proportion of cell clumps regenerating neurites in the presence of $50 \mathrm{ng} / \mathrm{ml}$ NGF, less the number of cell clumps regenerating neurites in the absence of added growth factors; these proportions were 74 and $20 \%$, respcctivcly. Comparablc rcsults were obtained in another, independent experiment with bovine $\mathrm{bFGF}$. response of PC12 cells to bFGF. In addition, heparin does not alter the response of $\mathrm{PC} 12$ cells to NGF (data not shown).

Priming and neurite regeneration. The initiation of neurite outgrowth in PC12 cell cultures by NGF is a transcriptiondependent event blocked by low concentrations of RNA-synthesis inhibitors. In contrast, NGF-dependent neurite regeneration by $\mathrm{PC} 12$ cells pretreated with the factor for 1-2 weeks is not blocked even by high concentrations of such inhibitors (Burstein and Greene, 1978). The transcription-dependent events that PC12 cells undergo, which enable them to initiate neurite outgrowth and to exhibit transcription-independent neurite regeneration, have been termed "priming" (Burstein and Greene, 1978).

Basic FGF has previously been reported to promote neurite regeneration from NGF-primed PC1 2 cells, but to lack the ability to prime PC12 cells (Togari et al., 1985). In agreement with the work of Togari et al. (1985), both bovine and human bFGF were found to promote neurite regeneration from NGF-primed PC1 2 cells (Fig. 5). In each case, regeneration-promoting activity was detectable in the low picomolar range. Maximal neurite regeneration was promoted at a bovine bFGF concentration of $5 \mathrm{ng} / \mathrm{ml}$ (300 pM), while human bFGF had maximal effects at $50 \mathrm{ng} / \mathrm{ml}(3 \mathrm{nM})$. Furthermore, as is the case with NGF, bFGFinduced regeneration of neurites is transcription-independent (Fig. $4 E$ ). Cultures of PC1 2 cells were treated for 2 weeks with either bFGF or NGF divested of their processes by mechanical disruption, and subcultured in the presence of $10 \mu \mathrm{M}$ actinomycin D and one of the factors. At the concentration employed, actinomycin D blocks over $95 \%$ of uridine incorporation in PC1 2 cultures (Burstein and Greene, 1978), but does not inhibit bFGF-induced neurite regeneration (Fig. 4). However, this rapid regencration of ncurites is consistently greater with NGF than with bFGF treatment (compare Fig. $4, E$ and $F$ ), as was previously noted for the initiation of neurite outgrowth (Fig. 1, $E$, $F$ ).

Additional studies revealed that bFGF is also capable of priming PC1 2 cells. Figure $4, G, H$, shows that both bFGF and NGF, respectively, can initiate rapid, transcription-independent re-

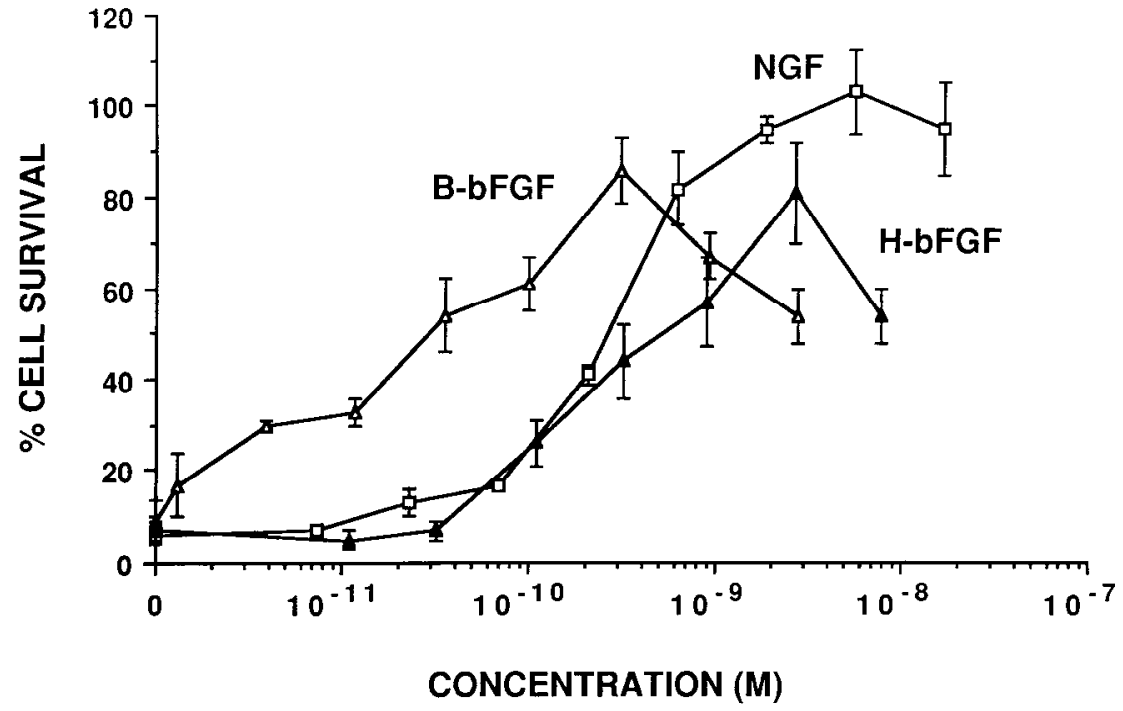

Figure 6. Dose-response relationship for the effects of bovine bFGF and human bFGF on survival of PC12 cells in serum-free medium. Serum-containing cultures of $\mathrm{PC} 12$ cells were washed 3 times with serum-free medium and then maintained in the absence of serum and in the presence of $5 \mathrm{ng} / \mathrm{ml} \mathrm{bo-}$ vine (B) bFGF (open triangles), $50 \mathrm{ng}$ / $\mathrm{mI} \mathrm{NGF} \mathrm{(open} \mathrm{boxes),} \mathrm{or} 50 \mathrm{ng} / \mathrm{ml} \mathrm{hu}-$ man $(\mathrm{H}) \mathrm{bFGF}$ (filled triangles). After $7 \mathrm{~d}$, cell counts were performed by removing the culture medium and dissolving the cells in a detergent lysing solution, and counting the nuclei using a hemacytometer (see Materials and Methods). Points represent the average of values obtained from triplicate cultures. Vertical bars show SD for counts of at least 1000 cells. Results are expressed relative to the proportion of cells initially present $\left(0.5-1 \times 10^{6}\right)$. 


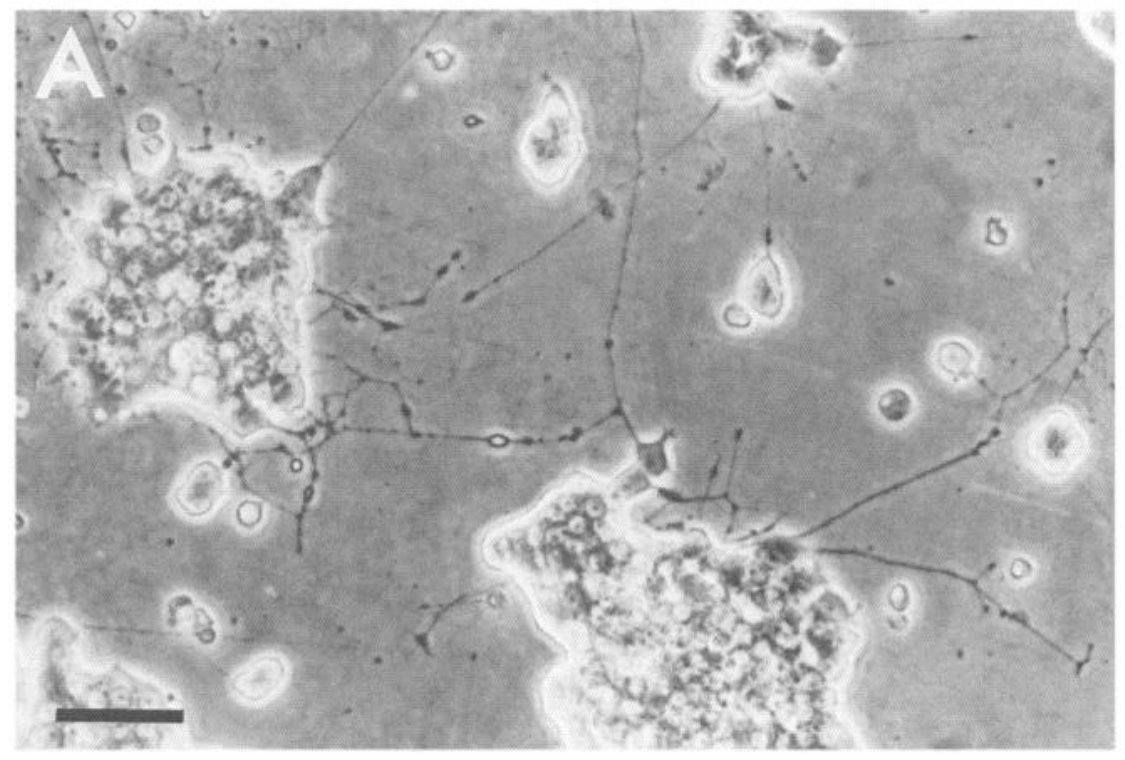

Figure 7. Survival and morphological differentiation of $\mathrm{PC} 12$ cells in serumfree medium induced by bFGF. PC12 cells $\left(5.2 \times 10^{4} / \mathrm{cm}^{2}\right)$ were maintained in the absence of serum and in the presence of $5 \mathrm{ng} / \mathrm{ml}$ bovine $\operatorname{bFGF}(A)$ or 50 $\mathrm{ng} / \mathrm{ml} \mathrm{NGF}(B)$ for $7 \mathrm{~d}$. Bar, $50 \mu \mathrm{m}$.

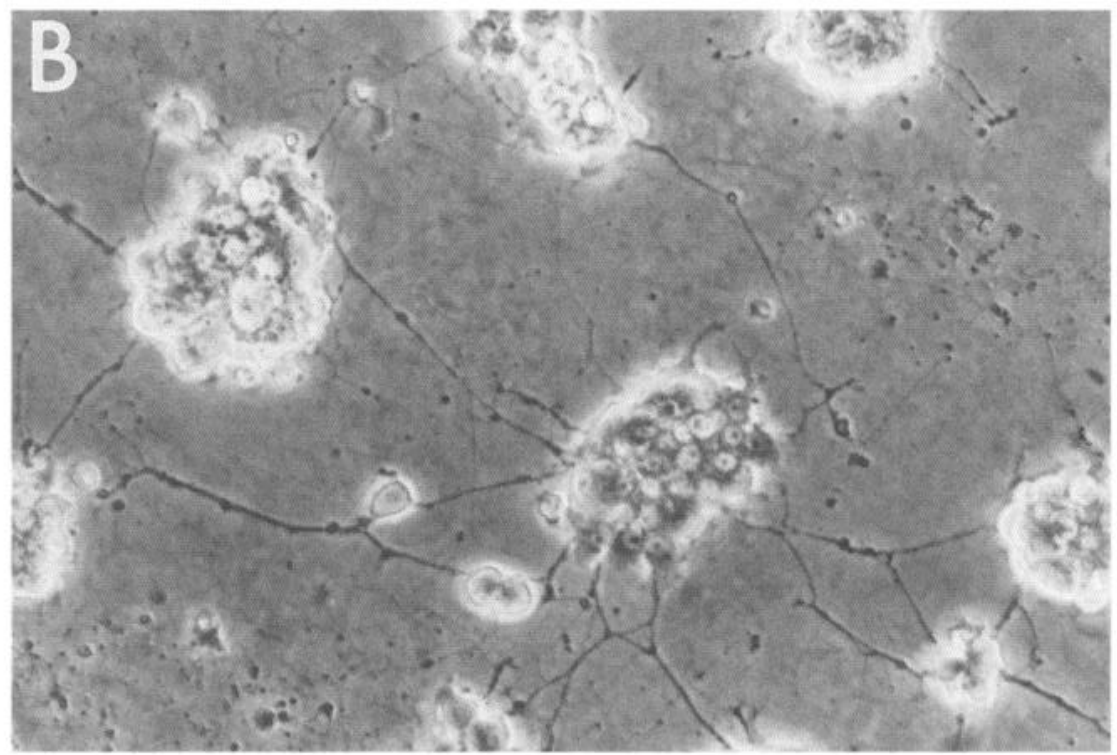

generation of neurites from bFGF-pretreated cells. However, the neurite-regeneration response of bFGF-primed cells to bFGF treatment was always much less robust in comparison to the other 3 conditions. Basic FGF- or NGF-primed cells subcultured in the absence of added growth factor did not display neuritic processes, nor did CM enhance bFGF- or NGF-induced neurite regeneration by primed cells (data not shown).

\section{Survival and morphological differentiation in serum-free medium}

Under the previously described growth conditions (Greene and Tischler, 1976) in serum-containing medium (85\% RPMI 1640 , $10 \%$ heat-inactivated horse serum, $5 \%$ fetal bovine serum, and no NGF), PC12 cells show excellent viability and growth. In contrast, PC12 cells are not viable in RPMI 1640 medium lacking serum. However, supplementation of serum-free medium with NGF promotes both PC12 cell survival and neuronal differentiation (Greene, 1978). As shown in Figure 6, bovine bFGF can also maintain cell viability in serum-free cultures of $\mathrm{PC} 12$ cells, and does so in a concentration-dependent manner. Optimal survival was observed at a bovine bFGF concentration of $5 \mathrm{ng} / \mathrm{ml}(300 \mathrm{pM})$, with half-maximal effects at $300 \mathrm{pg} / \mathrm{ml}(20$ pM). These concentrations are in close agreement with the doseresponse relationship observed for the mitogenic response of bovine bFGF on endothelial cells (Gospodarowicz et al., 1984; Thomas and Gimenez-Gallego, 1986). Furthermore, in this type of assay, bovine bFGF is about an order of magnitude more potent than NGF (Fig. 6). The data in Figure 6 also reveal that increasing the concentration of bovine bFGF above $5 \mathrm{ng} / \mathrm{ml}$ resulted in a loss of cell viability. Basic FGF-promoted survival of cerebral cortical neurons has also been reported to diminish with supraoptimal concentrations of bFGF (Morrison et al., 1986).

In agreement with its potency in promoting neurite initiation and regeneration (see above), human bFGF promoted optimal cell survival at $50 \mathrm{ng} / \mathrm{ml}(3 \mathrm{nM})$, with half-maximal effectiveness 
at about 4-6 ng/ml (200-300 pM). Moscatelli et al. (1986) have reported that this preparation of $b F G F$ promotes mitosis of bovine capillary endothelial cells, with a half-maximal concentration of $1 \mathrm{ng} / \mathrm{ml}$ (50 pM).

In addition to preventing the death of $\mathrm{PC} 12$ cells in serumfrec medium, bFGF also induces their morphological differentiation. As shown in Figure 7, the response of PC1 2 cells to bFGF in serum-free medium appears to be quite similar to that with NGF. The density of neurite outgrowth of both NGF- and FGF-treated cells in serum-free medium (Fig. 7) always appeared similar to that of $\mathrm{bFGF}$ in serum-containing medium (Fig. 1A). Furthermore, as with NGF (Greene, 1978), the neurites of cells grown in serum-free medium with bFGF were finer and showed less fasciculation than did those grown in the presence of serum.

\section{Cell division rate}

One of the responses of PC12 cells to NGF is cessation of replication (Greene and Tischler, 1976). The doubling time for PC12 cells in complete growth medium lacking either FGF or NGF is approximately $3 \mathrm{~d}$ (Greene and Tischler, 1976; Fig. 8). As shown in Figure 8 , by $7 \mathrm{~d}$ of exposure to bFGF, the cell number per dish remains at a near-constant level. The absence of debris in the medium indicates that this is due to cessation of multiplication rather than to cell death. This effect of bFGF occurs with a time course identical to that observed with NGF treatment (Fig. 8).

\section{Rapid changes in protein phosphorylation}

Further experiments were performed to test whether, in addition to promotion of neurite outgrowth and maintenance of survival, FGF could also elicit biochemical responses in PC12 cultures similar to those brought about by NGF. One rapid, transcription-independent response of PC1 2 cells to NGF is a change in the phosphorylation of specific cytoplasmic and nuclear proteins (Halegoua arid Patrick, 1980; Yu et al., 1980). These changes involve both increases (Halegoua and Patrick, 1980; Yu et al., 1980) and decreases (End et al., 1983) in the level of phosphorylation of specific proteins. We therefore compared cytoplasmic (Triton X-100-soluble) proteins of $\mathrm{PC} 12$ cells labeled during 2 hr of exposure to ${ }^{32} \mathrm{P}$-orthophosphate with either bFGF, NGF, or an equal volume of RPMI 1640 added during the second hour of incubation. As shown in Figure 9, the general pattern of protein phosphorylation following exposure to either bFGF or NGF is quite similar. Compared to untreated controls, densitometric scans reveal that there was a significant increase (2.6fold for the experiment shown) in the incorporation of ${ }^{32} \mathrm{P}$ into a band with a $M_{\mathrm{r}} \simeq 60 \mathrm{kDa}$. This effect is shown more clearly by the lower gain scan on the right of Figure 9 . All or most of the responsive $60 \mathrm{kDa}$ band has been identified as being composed of tyrosine hydroxylase (Halegoua and Patrick, 1980; Lee et al., 1985). In addition, as previously reported by Togari et al. (1985), both NGF and bFGF led to an inhibition of the phosphorylation of a band with a $M_{1} \simeq 100 \mathrm{kDa}$.

\section{Long-term changes in protein phosphorylation}

In addition to promoting rapid biochemical responses in $\mathrm{PC} 12$ cells, NGF also elicits long-term, transcription-dependent changes. Among these is an induction in the level of a highmolecular-weight, microtubule-associated phosphoprotein designated MAP1.2 (Greene et al., 1983; Drubin et al., 1985). This effect has been found to be independent of neurite outgrowth,

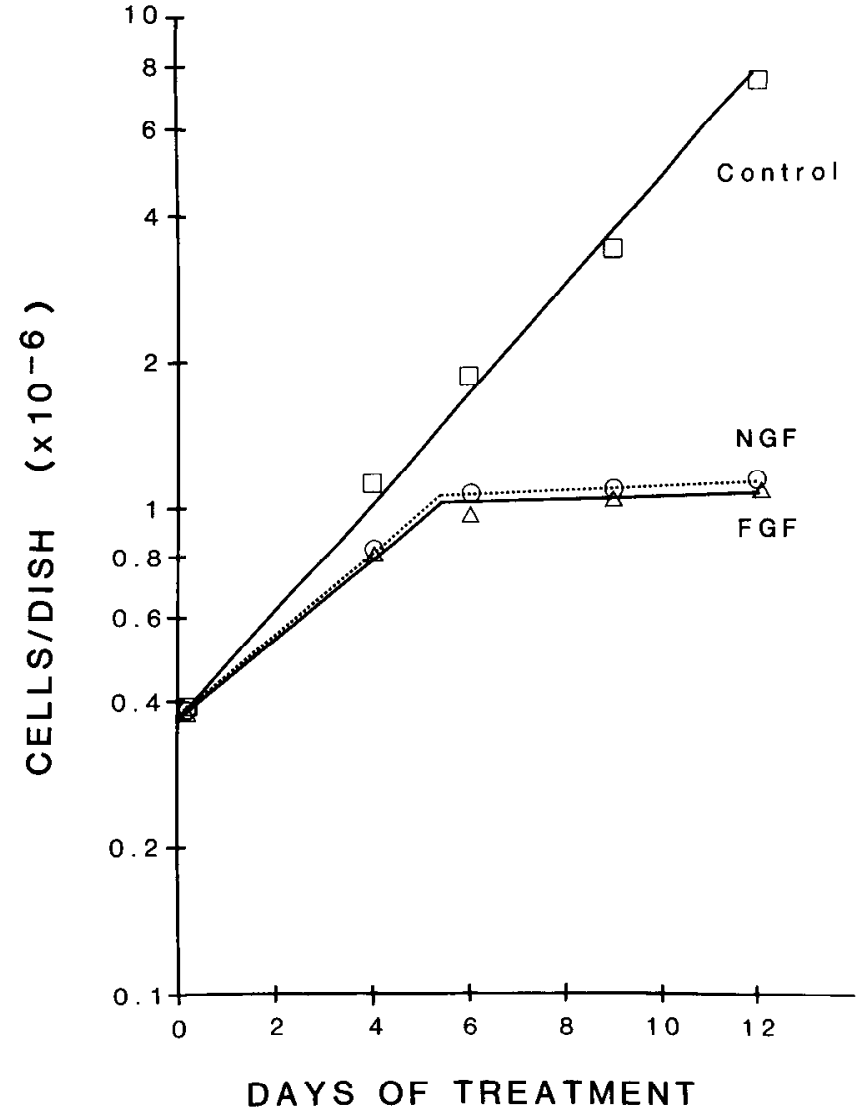

Figure 8. Effect of bFGF on PC12 cell growth. Growth rates were determined for PC12 cells (starting density, $3.8 \times 10^{4} / \mathrm{cm}^{2}$ ) maintained in complete growth medium (solid line, boxes), or in the presence of 5 $\mathrm{ng} / \mathrm{ml}$ bovine bFGF (solid line, triangles) or $50 \mathrm{ng} / \mathrm{ml} \mathrm{NGF} \mathrm{(dashed}$ line, circles). Cell counts were determined as in Figure 6. Points represent the average of values obtained with duplicate cultures. For each treatment, at least 1000 cells were counted.

and is not mimicked by epidermal growth factor (EGF), dibutyryl cyclic AMP (dbcAMP), or insulin (Greene et al., 1983). To test the efficacy of FGFs in this regard, cultures of $\mathrm{PC} 12$ cells were treated with either bFGF or NGF for 12-13 d and then exposed to ${ }^{32} \mathrm{P}$-orthophosphate for $2 \mathrm{hr}$. In some experiments, cultures were maintained in $\mathrm{CM}$ to allow for maximal neurite outgrowth. Figure $10, A$ and $B$, shows that a band at $M_{\mathrm{r}} \simeq 300 \mathrm{kDa}$ was induced by over 15 -fold in response to longterm treatment with either bFGF or NGF. This band has previously been identified as MAP1.2 in long-term NGF-treated cultures of PC1 2 cells (Greene et al., 1983; Drubin et al., 1985; J. M. Aletta, N. Cowan, S. Lewis, and L. A. Greene, unpublished observations). A second band at $M_{\mathrm{r}} \simeq 130 \mathrm{kDa}$ showed a major increase in labeling after long-term treatment with either bFGF or NGF, while a band at $M_{\mathrm{r}} \simeq 55 \mathrm{kDa}$ showed a minor increase with either treatment. In addition, bands at $M_{\mathrm{r}} \simeq 40 \mathrm{kDa}$ and $34 \mathrm{kDa}$ showed slight decreases in ${ }^{32} \mathrm{P}$ labeling following bFGF or NGF treatment. CM alone had no effect on the phosphorylation pattern of PC1 2 cells with either short- or long-term treatment, and was not required for bFGF induction of MAP1.2.

\section{Glycoproteins}

Long-term treatment of PC12 cells with NGF produces 2 major transcription-requiring changes in their cellular glycoprotein 


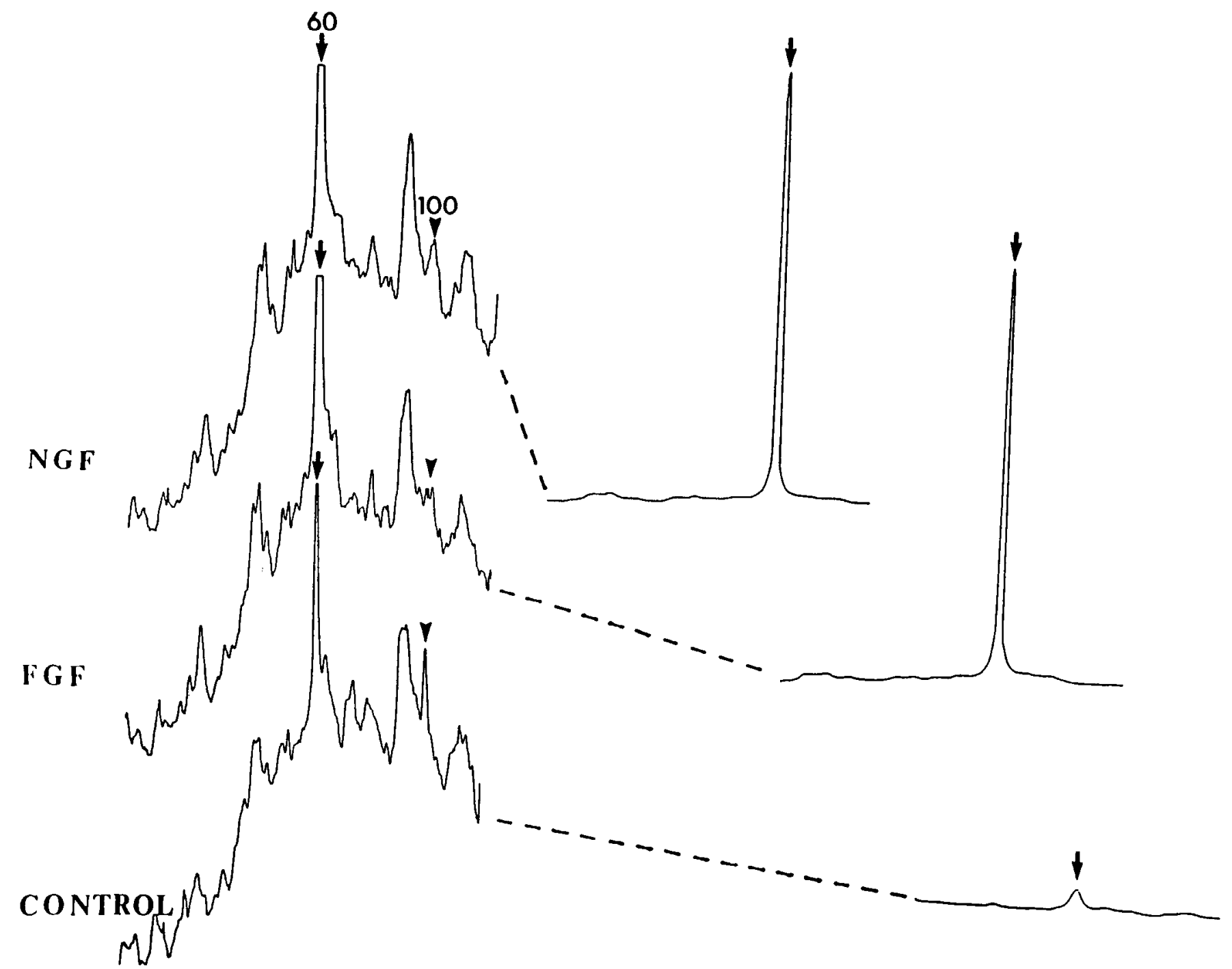

Figure 9. Rapid effects of bFGF and NGF on the phosphorylation of soluble proteins in PC12 cells. Cells $\left(10^{5} / \mathrm{cm}^{2}\right)$ were maintained in serumfree medium for $12 \mathrm{hr}$ and then labeled as described in Materials and Methods with ${ }^{32} \mathrm{P}$-orthophosphate for $2 \mathrm{hr}$. Cultures received either $50 \mathrm{ng} /$ $\mathrm{ml} \mathrm{NGF}$ (upper scan), $5 \mathrm{ng} / \mathrm{ml}$ bovine bFGF (middle scan), or no treatment (bottom scan) during the last hour of incubation. Soluble proteins were extracted with Triton X-100 and dissolved in $4 \times$ sample buffer. Equal amounts of TCA-precipitable radioactivity were subjected to SDS-PAGE and the resolved proteins were detected by autoradiography. Scans of the autoradiograms are shown, with the origin of electrophoresis to the right and the positions of $60 \mathrm{kDa}$ (arrow) and $100 \mathrm{kDa}$ (arrowhead) phosphoproteins indicated. The relative level of phosphate incorporation into the $60 \mathrm{kDa}$ band is shown by the lower gain scans to the right and increased 2.6- and 2.7-fold for bFGF and NGF, respectively. Comparable results were obtained in 2 additional, independent experiments.

composition. These are an increase in a $25 \mathrm{kDa}$ glycoprotein (McGuire et al., 1978), which has been identified as Thy-1 and shown not to be increased following exposure to dbcAMP or epidermal growth factor (EGF) (Richter-Landsberg et al., 1985), and an increase in the $230 \mathrm{kDa}$ NGF-inducible large external (NILE) glycoprotein (McGuire et al., 1978; Salton et al., 1983). Both of these glycoproteins can be easily distinguished from other species by SDS-PAGE. To compare bFGF to NGF with respect to their effects on $\mathrm{PC} 12$ cell glycoprotein composition, cultures were treated for 5 or $20 \mathrm{~d}$ with either factor. The cultures were metabolically labeled with ${ }^{3} \mathrm{H}$-fucose during the last $3 \mathrm{~d}$ of treatment, and their glycoproteins were analyzed by SDSPAGE and fluorography. The relative level of NILE glycoprotein labeling was detectably enhanced after $5 \mathrm{~d}$ of bFGF treatment, and increased 3.8 -fold after $20 \mathrm{~d}$ (Fig. 11). The magnitude of these effects was comparable to that obtained with NGF in this (Fig. 11) and other experiments. Incorporation of ${ }^{3} \mathrm{H}$-fucose into Thy-1 was also increased within $5 \mathrm{~d}$ with either bFGF or NGF treatment (Fig. 11, lanes $A, B$ ). This 2.4-fold increase in Thy-1 glycoprotein appears to be due to changes in the level of transcription of the Thy-1 gene, since Thy-1 mRNA is also significantly increased after $3 \mathrm{~d}$ of exposure to bFGF (Drcxlcr and Greene, 1986).

The relative labeling of Thy- 1 glycoprotein often returns to control levels after NGF treatment for $10 \mathrm{~d}$ or longer (RichterLandsberg et al., 1985), but occasionally remains elevated for longer periods. In the particular experiment shown in Figure 11, the Thy-1 labeling in the culture exposed to bFGF returned to near-control levels by day 20 , while that in the NGF-treated culture did not. In other experiments (not shown) the level of Thy- 1 labeling in cultures treated with bFGF for over $10 \mathrm{~d}$ did not fall. 


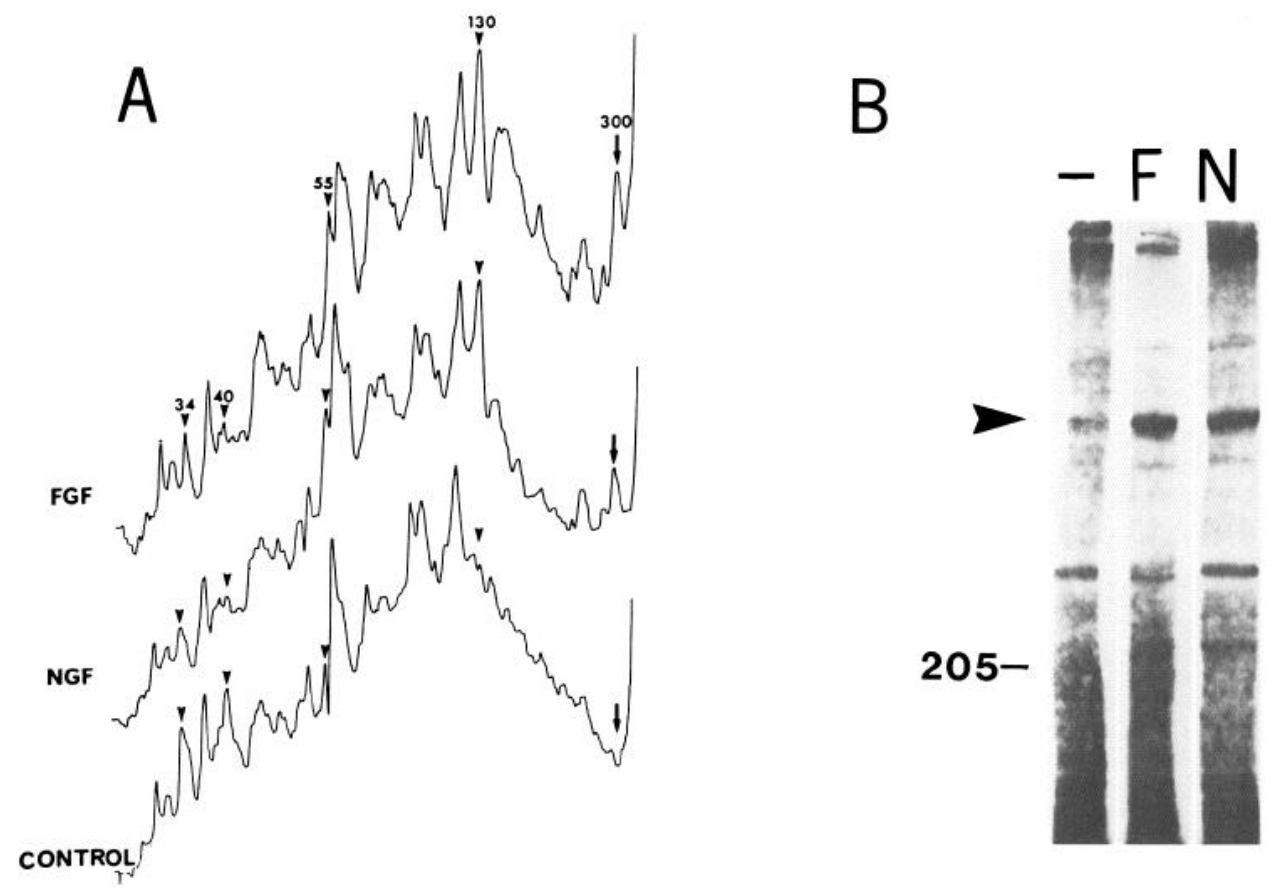

Figure 10. Long-term induction of MAP1.2 phosphoprotein in PC12 cells by bFGF. A, Cultures of PC12 cells $\left(10^{4} / \mathrm{cm}^{2}\right)$ were treated with either $5 \mathrm{ng} / \mathrm{ml}$ bovine bFGF (upper scan) or $50 \mathrm{ng} / \mathrm{ml} \mathrm{NGF}$ (middle scan) in the presence of conditioned medium (CM) for $13 \mathrm{~d}$ and then exposed to ${ }^{32} \mathrm{P}$-orthophosphate for $2 \mathrm{hr}$. Control cultures (lower scan) were maintained in CM alone. Cells were dissolved in sample buffer and equal amounts of TCA-precipitable radioactivity were subjected to SDS-PAGE on 32-cm 7.5-15\% linear gradient polyacrylamide gels, and the resolved phosphoproteins detected by autoradiography. Scans of the autoradiograms are shown, with the origin of electrophoresis to the right and the position of MAP1.2 $\left(M_{\mathrm{r}} \simeq 300 \mathrm{kDa}\right)$ indicated by an arrow. Densitometric scanning of autoradiograms from duplicate cultures averaged 17.2-fold (bFGF) and 15.4-fold (NGF) increases in the level of phosphate incorporation into this $300 \mathrm{kDa}$ band. Other consistently observed changes in the relative levels of various phosphoproteins are indicated by arrowheads and discussed in the text. $B$, Cultures $\left(10^{5} \mathrm{cells} / \mathrm{cm}^{2}\right)$ were treated with either $50 \mathrm{ng} /$ $\mathrm{ml}$ human bFGF $(F)$ or $50 \mathrm{ng} / \mathrm{ml} \mathrm{NGF}(N)$ in the presence of $1 \%$ horse serum (HS) for $12 \mathrm{~d}$ and then exposed to ${ }^{32} \mathrm{P}$-orthophosphate for $2 \mathrm{hr}$. Control cultures (-) were maintained in $1 \%$ HS alone. The position of MAP1.2 (arrowhead) and the myosin standard $\left(M_{r} \simeq 205,000\right)$ are indicated. Sample preparation and electrophoresis were carried out as in $A$ except that $15-\mathrm{cm}$ gels containing $4 \mathrm{~m}$ urea and $3.25 \%$ polyacrylamide were used.

\section{AChE activity}

Figure 12 shows the relationship between FGF or NGF treatment and AChE-specific activity in cultures of PC1 2 cells. NGF has been demonstrated to induce an increase in AChE-specific activity in PC12 cultures (Lucas et al., 1980; Rieger et al., 1980). This effect has been shown to be transcription-dependent and neither mimicked nor altered by EGF, dexamethasone, or dbcAMP (Greene and Rukenstein, 1981). Togari et al. (1985) reported that bovine pituitary bFGF failed to affect $\mathrm{AChE}$ activity in $\mathrm{PCl} 2$ cells after $3 \mathrm{~d}$ of treatment. In the present studies, human $\mathrm{bFGF}(50 \mathrm{ng} / \mathrm{ml})$ was found to stimulate AChE-specific activity in PC12 cell cultures to an extent similar to that of NGF after both 3 and $10 \mathrm{~d}$ of exposure. Moreover, when tested after $10 \mathrm{~d}$ of exposure, this approximately 2-fold stimulation was mimicked by bovine bFGF ( $5 \mathrm{ng} / \mathrm{ml})$. Bovine aFGF at $10 \mathrm{ng} /$ $\mathrm{ml}$ also brought about a similar increase, but, consistent with its effects on neurite outgrowth, only in the presence of $50 \mu \mathrm{g} /$ $\mathrm{ml}$ heparin. Treatment of PC12 cells with heparin alone had no effect on AChE-specific activity, nor did it alter the effects of bFGF or NGF (data not shown).

\section{Discussion}

Comparison of responses to NGF and to FGFS

Acidic and basic FGFs are peptide hormones, characterized mainly by their potent mitogenic and angiogenic activity. Both factors share the same spectrum of responsive cells (Gospodarowicz et al., 1986; Thomas and Gimenez-Gallego, 1986) and probably mediate their responses through the same receptor species (Neufeld and Gospodarowicz, 1986). In contrast to its mitogenic activity in most responsive cells, the present findings demonstrate that bFGF causes the cessation of cell division in cultures of $\mathrm{PC} 12$ cells and, furthermore, can reproduce the entire spectrum of $\mathrm{PC} 12$ cell responses previously shown to be elicited by NGF. These include responses that are rapid (cell flattening, enhanced phosphorylation of tyrosine hydroxylase) or delayed (neurite outgrowth, induction of phosphorylated MAP1.2, regulation of NILE and Thy-1 glycoproteins, cessation of 1initosis, elevation of AChE activity), as well as responses that have been shown to be either transcription-independent (neurite regeneration, promotion of survival) or transcription-dependent (priming, regulation of NILE and Thy-1 glycoproteins, elevation of AChE activity). Positive results were also achieved for each of the responses tested with aFGF (promotion of neurite outgrowth and regeneration, elevation of AChE activity). These represent both short- and long-term, transcription-independent and transcription-dependent, responses, indicating that aFGF's spectrum of responses in PC12 cells is probably identical to that of $\mathrm{NGF}$ and bFGF.

Additional PC12 cell studies have shown that, in common with NGF, bFGF can also rapidly and transiently stimulate transcription of the c-fos, c-myc, and actin genes (Greenberg et 
Figure 11. Effects of bFGF on the labeling of Thy-1 and NILE glycoproteins in PC12 cells. Cultures of PC12 cells $\left(10^{5} / \mathrm{cm}^{2}\right)$ in complete growth medium were labeled by exposure to ${ }^{3} \mathrm{H}$-fucose for $3 \mathrm{~d}$ in the absence of, or during the last $3 \mathrm{~d}$ of, bFGF or NGF treatment. $A$, Treated with $50 \mathrm{ng} / \mathrm{ml}$ human bFGF for $5 \mathrm{~d}$. $B$, Treated with $50 \mathrm{ng} /$ $\mathrm{ml} \mathrm{NGF}$ for $5 \mathrm{~d}$. $C$, Untreated $5 \mathrm{~d}$ control. $D$, Untreated $20 \mathrm{~d}$ control. $E$, Treated with $5 \mathrm{ng} / \mathrm{ml}$ bovine bFGF for $20 \mathrm{~d} . F$, Treated with $50 \mathrm{ng} / \mathrm{ml} \mathrm{NGF}$ for $20 \mathrm{~d}$. Cells were dissolved in sample buffer, equal amounts of radioactivity subjected to SDS-PAGE, and glycoproteins were detected by fluorography. The positions of molecular-weight standards are given on the left as $M_{\mathrm{r}}$ $\left(\times 10^{-3}\right)$. Arrowheads on the left indicate the positions of the NILE $\left(M_{\mathrm{r}} \simeq 230\right.$ $\mathrm{kDa})$ and Thy-1 $\left(M_{\mathrm{r}} \simeq 25 \mathrm{kDa}\right)$ glycoproteins. Densitometric scanning revealed that the incorporation of ${ }^{3} \mathrm{H}-\mathrm{fu}$ cose into Thy-1 was increased 2.4- and 1.7 -fold by bFGF and NGF, respectively, after 5 d. A 3.8 - and 3.5 -fold increase in the level of NILE glycoprotein labeling was observed for $\mathrm{bFGF}$ and NGF, respectively, after $20 \mathrm{~d}$. Comparable results were obtained in 2 independent experiments.

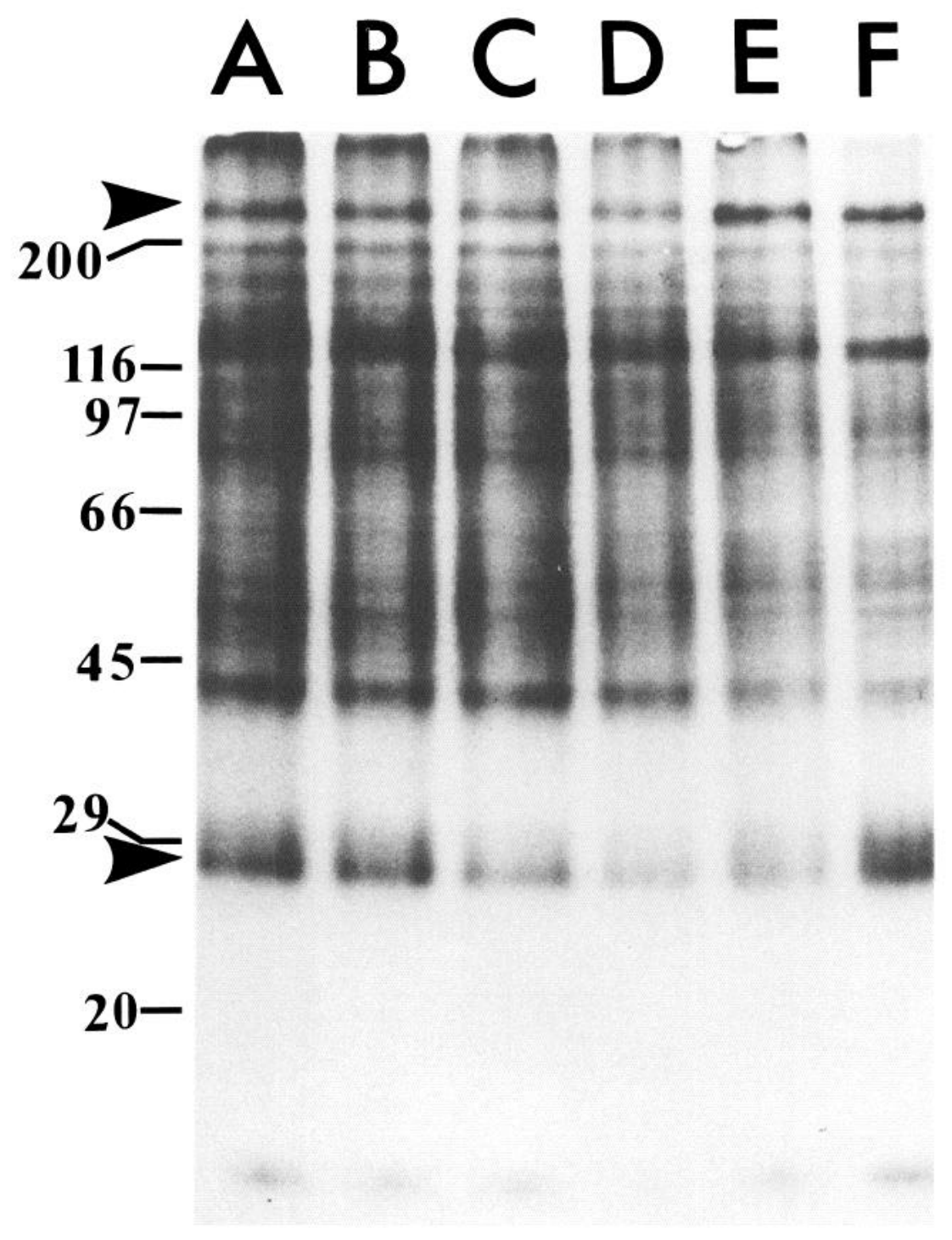

in the cell than by any inherent activity associated with the factor itself. Thus, some mechanistic elements may well be shared between NGF and the FGFs.

\section{FGF-promoted neurite outgrowth}

The only responses for which the FGFs and NGF consistently showed quantitative differences were the rates for neurite initiation and elongation in serum-containing medium. Thus, while all 3 factors promoted the formation of stable neurites, the network of outgrowth elicited by NGF at any given time of treatment was always of greater density. This differential response does not appear to be due to a reduced stability or enhanced degradation of FGFs, since decreasing the interval between administration of bFGF did not alter the density of neurite outgrowth. When neurite outgrowth was observed in serum-free medium, the differences between NGF and bFGF were no longer apparent. This suggests that serum factors may differentially modulate cellular responses to the 2 factors.

Cell density was also observed to affect the rate of neurite initiation after treatment with bFGF or NGF. Outgrowth was more rapid when the cell density was increased from 10,000 to 50,000 cells $/ \mathrm{cm}^{2}$. This appeared to be due, at least in part, to governed more by the transduction mechanisms available with- 


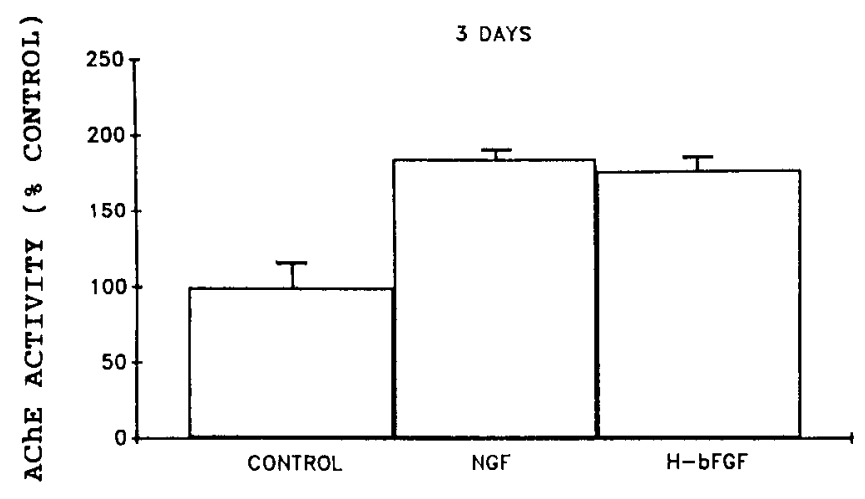

10 DAYS

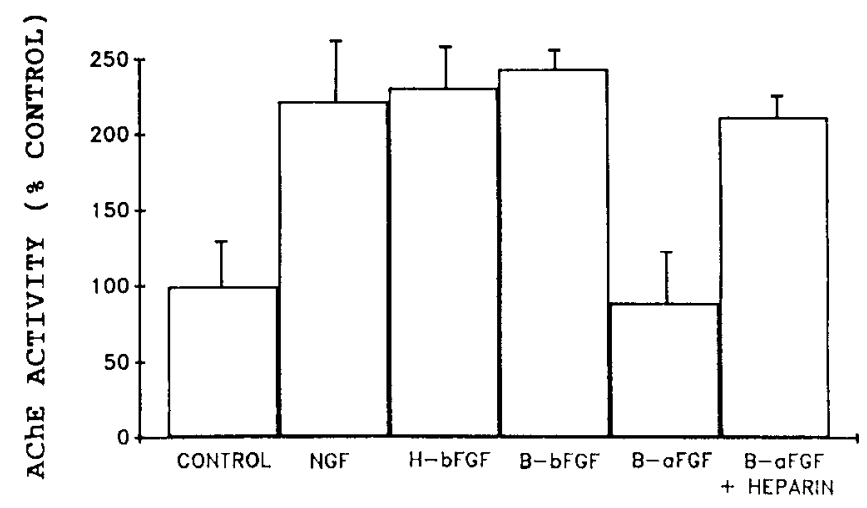

Figure 12. Effects of aFGF and bFGF on AChE activity in PC1 2 cells. Cells $\left(5.2 \times 10^{4} / \mathrm{cm}^{2}\right)$ were cultured for $3 \mathrm{~d}$ (upper panel) or $10 \mathrm{~d}$ (lower panel) with the indicated treatments. Control values for AChE activity were $5.2 \mathrm{nmol}$ of acetylthiocholine hydrolyzed $/ \mathrm{min} / \mathrm{mg}$ protein ( $3 \mathrm{~d}$ ) and $14.3 \mathrm{nmol}$ of acetylthiocholine hydrolyzed $/ \mathrm{min} / \mathrm{mg}$ protein $(10 \mathrm{~d})$. When present, additives were at the following concentrations: NGF, $50 \mathrm{ng} / \mathrm{ml}$; human (H) bFGF, $50 \mathrm{ng} / \mathrm{ml}$; bovine (B) bFGF, $5 \mathrm{ng} / \mathrm{ml}$; bovine (B) aFGF, $10 \mathrm{ng} / \mathrm{ml}$; heparin, $50 \mu \mathrm{g} / \mathrm{ml}$. Vertical bars show SD for measurement of 3-5 cultures. Comparable results were obtained in 3 and 2 independent experiments at the $3 \mathrm{~d}$ and $10 \mathrm{~d}$ time points, respectively.

soluble material released from the cells, since addition to lowdensity cultures of medium conditioned by high-density cultures produced enhancement in the responses to both bFGF and NGF. Many cell types, including PC12 cells, release into conditioned medium substainces that cause neurons to extend neurites both sooner and more rapidly than in their absence (reviewed in Berg, 1984). These substances fall into 2 categories: factors that act as a component of the culture substratum and that promote neurite outgrowth even in the absence of a neurotrophic agent, and factors that do not absorb to the substratum and have no detectable effects on neurite outgrowth by themselves. The PC12 $\mathrm{CM}$ has not been characterized with regard to its possible action as a substrate-conditioning factor, but it clearly does not act as an NGF-like molecule for $\mathrm{PC} 12$ cells. In the absence of FGFs or NGF, CM has no effect on neurite initiation, neurite regeneration, or protein phosphorylation. While CM enhanced both NGF- and FGF-promoted neurite outgrowth in a qualitatively similar manner, outgrowth elicited by the FGFs was nevertheless always less dense.

Togari et al. $(1983,1985)$ have previously reported that bFGF can initiate neurite formation in PC12 cell cultures. However, the processes that were formed were relatively short, resembled those produced by exposure to cAMP analogs, and were found to retract within 3-6 d of treatment. In contrast, the present study demonstrates that aFGF- and bFGF-elicited processes are able to reach many hundreds of micrometers in length, that they are similar to those promoted by NGF, and that they are stable for at least 1 month (the longest time tested). In addition, whereas Togari et al. (1985) noted no effect of bFGF on AChE activity, the present study finds regulation of this enzyme by both FGFs. One possible basis for these differences is the source of the FGFs. The work of Togari et al. (1985) used primarily commercially prepared bFGF of uncertain purity, while the FGFs available for the present studies were highly purified. It may be that such commercially supplied bFGF was more rapidly inactivated or degraded, or contained inhibitory activities, thereby interfering with the expression of long-term responses to this factor. Consistent with this possibility is the observation of Togari et al. (1985) that the bFGF they employed promoted responses of rapid onset, such as specific changes in protein phosphorylation and induction of ornithine decarboxylase activity, but failed to elicit delayed responses, such as induction of $\mathrm{AChE}$ activity and stable growth of long neurites.

\section{Biological implications}

Although the PC12 line shares many properties with sympathetic neurons, it has been found that neither aFGF nor bFGF promotes survival or neurite outgrowth in cultures of neonatal rat superior cervical ganglionic neurons or of rat embryonic day 15 dorsal root ganglionic neurons (Rydel and Greene, 1987). It may be that such neurons lack FGF receptors, at least at the ages at which they were tested. The presence of FGF responses in PC12 cell cultures may therefore suggest cither that these pheochromocytoma cells differ from their neuronal counterparts by having acquired FGF receptors, or that the FGFs may affect sympathetic neurons or their precursors at stages of development different from those analyzed thus far.

Despite the apparent lack of effect of either form of FGF on peripheral neurons, 2 very recent studies (Morrison et al., 1986; Walicke et al., 1986) have demonstrated that bFGF promotes the survival and outgrowth of neurites from cultured CNS neurons. The present observations have described a variety of additional actions of bFGF on a neuronal cell line and demonstrate that aFGF is capable of mimicking many, if not all, of these actions. These observations thus extend the range of actions that aFGF and bFGF may potentially exert on nerve cells, during either their development, repair, or maintenance. In addition, since PC12 cells are often used as a bioassay for the detection of putative neurotrophic agents (Edgar et al., 1979), it is quite possible that aFGF or bFGF may account for the neurotrophic activities found with various brain extracts.

The PC1 2 cell line has served as a highly useful model system with which to study the mechanism of action of NGF on neurons. The present work suggests that this cell line may also serve in a similar manner for mechanistic studies of acidic and basic FGF. Furthermore, since all 3 factors appear capable of eliciting the same wide spectrum of responses, molecular events specifically associated with FGFs and NGF in PC12 cells may prove to illuminate the causal steps involved in neuronal differentiation.

\section{References}

Berg, D. K. (1984) New neuronal growth factors. Annu. Rev. Neurosci. 7: $149-170$. 
Bohlen, P., F. Esch, A. Baird, and D. Gospodarowicz (1985) Acidic fibroblast growth factor (FGF) from bovine brain: Amino-terminal sequence and comparison with basic FGF. EMBO J. 4: 1951-1956.

Burstein, D. E., and L. A. Greene (1978) Evidence for RNA synthesisdependent and -independent pathways in stimulation of neurite outgrowth by nerve growth factor. Proc. Natl. Acad. Sci. USA 75: 60596063.

Burstein, D. E., and L. A. Greene (1982) Nerve growth factor has both mitogenic and antimitogenic activity. Dev. Biol. 94: 477-482.

Drexler, S. A., and L. A. Greene (1986) Regulation of Thy-1 mRNA in PC12 cells by NGF and elevated potassium. Soc. Neurosci. Abstr. 12: 215

Drubin, D. G., S. C. Feinstein, E. M. Shooter, and M. W. Kirschner (1985) Nerve growth factor-induced neurite outgrowth in PC12 cells involves the coordinate induction of microtubule assembly and assembly-promoting factors. J. Cell Biol. 101: 1799-1807.

Edgar, D. H., Y.-A. Barde, and H. Thoenen (1979) Induction of fiber outgrowth and choline acetyltransferase in $\mathrm{PC} 12$ pheochromocytoma cells by conditioned media from glial cells and organ extracts. Exp. Cell Res. 121: 353-361.

End, D., N. Tolson, S. Hashimoto, and G. Guroff (1983) Nerve growth factor-induced decrease in the cell-free phosphorylation of a soluble protein in PC1 2 cells. J. Biol. Chem. 258: 6549-6555.

Esch, F., A. Baird, N. Ling, N. Ueno, F. Hill, L. Denoroy, R. Klepper, D. Gospodarowicz, P. Bohlen, and R. Guillemin (1985a) Primary structure of bovine basic fibroblast growth factor (FGF) and comparison with the amino-terminal sequence of bovine acidic FGF. Proc. Natl. Acad. Sci. USA 82: 6507-6511.

Esch, F., N. Ueno, A. Baird, F. Hill, L. Denoroy, N. Ling, D. Gospodarowicz, and R. Guillemin (1985b) Primary structure of bovine acidic fibroblast growth factor (FGF). Biochem. Biophys. Res. Commun. 133: 554-562.

Gimenez-Gallego, G., J. Rodkey, C. Bennett, M. Rios-Candelore, J. DiSalvo, and K. Thomas (1985) Brain-derived acidic fibroblast growth factor: Complete amino acid sequence and homologies. Science 230: 1385-1388.

Gospodarowicz, D., J. Cheng, G.-M. Lui, A. Baird, and P. Bohlen (1984) Isolation of brain fibroblast growth factor by heparin-Sepharose affinity chromatography: Identity with pituitary fibroblast growth factor. Proc. Natl. Acad. Sci. USA 81: 6963-6967.

Gospodarowicz, D., G. Neufeld, and L. Schweigerer (1986) Molecular and biological characterization of fibroblast growth factor, an angiogenic factor which also controls the proliferation and differentiation of mesoderm and neuroectoderm derived cells. Cell Differ. 19: 1-17.

Greenberg, M. E., L. A. Greene, and E. B. Ziff (1985) Nerve growth factor and epidermal growth factor induced rapid transient changes in proto-oncogene transcription in PC12 cells. J. Biol. Chem. 260: 14101-14110.

Greene, L. A. (1977) A quantitative bioassay for nerve growth factor (NGF) activity employing a clonal pheochromocytoma cell line. Brain Res. 133: 350-353.

Greene, L. A. (1978) Nerve growth factor prevents the death and stimulates the neuronal differentiation of clonal PC12 pheochromocytoma cells in serum-free medium. J. Cell Biol. 78: 747-755.

Greene, L. A. (1984) The importance of both early and delayed responses in the biological actions of nerve growth factor. Trends Neurosci. $7: 91-94$

Greene, L. A., and A. Rukenstein (1981) Regulation of acetylcholinesterase activity by nerve growth factor. J. Biol. Chem. 256: 63636367.

Greene, L. A., and E. M. Shooter (1980) The nerve growth factor: Biochemistry, synthesis, and mechanism of action. Annu. Rev. Neurosci. 3: 353-402

Greene, L. A., and A. S. Tischler (1976) Establishment of a noradrenergic clonal line of rat adrenal pheochromocytoma cells which respond to nerve growth factor. Proc. Natl. Acad. Sci. USA 73: 24242428 .

Greene, L. A., and A. S. Tischler (1982) PC12 pheochromocytoma cultures in neurobiological research. Adv. Cell. Neurobiol. 3: 373414.

Greene, L. A., D. E. Burstein, and M. M. Black (1982) The role of transcription-dependent priming in nerve growth factor promoted neurite outgrowth. Dev. Biol. 91: 305-316.

Greene, L. A., R. K. H. Liem, and M. L. Shelanski (1983) Regulation of a high molecular weight microtubule-associated protein in $\mathrm{PC} 12$ cells by nerve growth factor. J. Cell Biol. 96: 76-83.

Halegoua, S., and J. Patrick (1980) Nerve growth factor mediates phosphorylation of specific proteins. Cell 22: 571-581.

Korsching, S. (1986) The role of nerve growth factor in the CNS. Trends Neurosci. 9: 570-573.

Laemmli, U. K. (1970) Cleavage of structural proteins during the assembly of the head of bacteriophage T4. Nature 227: 680-685.

Lee, K. Y., P. J. Seeley, T. H. Müller, E. Helmer-Matyjek, E. Sabban, M. Goldstein, and L. A. Greene (1985) Regulation of tyrosine hydroxylase phosphorylation in $\mathrm{PC} 12$ pheochromocytoma cells by elevated $\mathrm{K}^{+}$and nerve growth factor: Evidence for different mechanisms of action. Mol. Pharmacol. 28: 220-228.

Leonard, D. G. B., E. B. Ziff, and L. A. Greene (1986) Identification and characterization of $m R N A s$ regulated by nerve growth factor in PC1 2 cells. Mol. Cell. Biol. (in press).

Lillien, L. E., and P. Claude (1985) Nerve growth factor is a mitogen for cultured chromaffin cells. Nature 317: 632-634.

Lobb, R. R., and J. W. Fett (1984) Purification of 2 distinct growth factors from bovine neural tissue by heparin affinity chromatography. Biochemistry 23: 6925-6929.

Lobb, R. R., J. W. Harper, and J. W. Fett (1986) Purification of heparin-binding growth factors. Anal. Biochem. 154: 1-14.

Lucas, C. A., A. Czlonkowska, and G. W. Kreutzberg (1980) Regulation of acetylcholinesterase by nerve growth factor in the pheochromocytoma PC1 2 cell line. Neurosci. Lett. 18: 333-337.

McGuire, J. C., L. A. Greene, and A. V. Furano (1978) NGF stimulates incorporation of fucose or glucosamine into an external glycoprotein in cultured rat PC12 pheochromocytoma cells. Cell $15: 357-365$.

Mobley, W. C., A. Schenker, and E. M. Shooter (1976) Characterization and isolation of proteolytically modified nerve growth factor. Biochemistry 15: 5543-5551.

Morrison, R. S., A. Sharma, J. De Vellis, and R. A. Bradshaw (1986) Basic fibroblast growth factor supports the survival of cerebral cortical neurons in primary culture. Proc. Natl. Acad. Sci. USA 83: 7537 7541 .

Moscatelli, D., M. Presta, and D. B. Rifkin (1986) Purification of a factor from human placenta that stimulates capillary endothelial cell protease production, DNA synthesis, and migration. Proc. Natl. Acad. Sci. USA 83: 2091-2095.

Neufeld, G., and D. Gospodarowicz (1986) Basic and acidic fibroblast growth factors interact with the same cell surface receptors. J. Biol. Chem. 261: 5631-5637.

Richter-I andsberg, C., L. A. Greene, and M. L. Shelanski (1985) Cell surface Thy-1-cross-reactive glycoprotein in cultured PC12 cells: Modulation by nerve growth factor and association with the cytoskeleton. J. Neurosci. 5: 468-476.

Rieger, F., M. L. Shelanski, and L. A. Greene (1980) The effects of nerve growth factor on acetylcholinesterase and its multiple forms in cultures of rat PC12 pheochromocytoma cells: Increased total specific activity and appearance of the 16S molecular form. Dev. Biol. 76 . 238-243.

Rydel, R. E., and L. A. Greene (1985) Growth factors, cAMP and elevated $\mathrm{K}^{+}$prevent the death of clonal $\mathrm{PCl} 2$ pheochromocytoma cells in serum-free medium. Soc. Neurosci. Abstr. 11: 935.

Rydel, R. E., and L. A. Greene (1987) Cyclic AMP analogs promote survival and neurite outgrowth in cultures of rat sympathetic and sensory neurons independently of nerve growth factor. Proc. Natl. Acad. Sci. USA (in press).

Salton, S. R. J., C. Richter-Landsberg, L. A. Greene, and M. L. Shelanski (1983) Nerve growth factor-inducible large external (NILE) glycoprotein: Studies of a central and peripheral neuronal marker. J. Neurosci. 3: 441-454.

Schreiber, A. B., J. Kenney, W. J. Kowalski, R. Friesel, T. Mehlman, and T. Maciag (1985) Interaction of endothelial cell growth factor with heparin: Characterization by receptor and antibody recognition. Proc. Natl. Acad. Sci. USA 82: 6138-6142.

Seeley, P. J., A. Rukenstein, J. L. Connolly, and L. A. Greene (1984) Differential inhibition of nerve growth factor and epidermal growth factor effects on the PC12 pheochromocytoma line. J. Cell Biol. 98. $417-426$

Solomon, F., M. Magendantz, and A. Salzman (1979) Identification with cellular microtubules of one of the co-assembling microtubuleassociated proteins. Cell 18: 431-438.

Sommer, A., M. T. Brewer, R. C. Thompson, D. Moscatelli, M. Presta, and D. B. Rifkin (1987) A form of basic human fibroblast growth 
factor with an extended amino terminus. Biochem. Biophys. Res. Comm. 144: 543-550.

Soto, A. M., and C. Sonnenschein (1985) The role of estrogens on the proliferation of human breast tumor cells (MCF-7). J. Steroid Biochem. 23: 87-94.

Thomas, K. A., and G. Gimenez-Gallego (1986) Fibroblast growth factors: Broad spectrum mitogens with potent angiogenic activity. Trends Biol. Sci. 11: 81-84.

Thomas, K. A., M. Rios-Candelore, and S. Fitzpatrick (1984) Purification and characterization of acidic fibroblast growth factor from bovine brain. Proc. Natl. Acad. Sci. USA 81: 357-361.

Togari, A., D. Baker, G. Dickens, and G. Guroff (1983) The neuritepromoting effect of fibroblast growth factor on PC12 cells. Biochem. Biophys. Res. Commun. 114: 1189-1193.

Togari, A., G. Dickens, H. Kuzuya, and G. Guroff (1985) The effect of fibroblast growth factor on PC12 cells. J. Neurosci. 5: 307-316.

Vinores, S., and G. Guroff (1980) Nerve growth factor: Mechanism of action. Annu. Rev. Biophys. Bioeng. 9: 223-257.
Walicke, P., W. M. Cowan, N. Ueno, A. Baird, and R. Guillemin (1986) Fibroblast growth factor promotes survival of dissociated hippocampal neurons and enhances neurite extension. Proc. Natl. Acad. Sci. USA 83: 3012-3016.

Westall, F. C., R. Rubin, and D. Gospodarowicz (1983) Brain-derived fibroblast growth factor: A study of its inactivation. Life Sci. 33: 24252429.

Yankner, B. A., and E. M. Shooter (1982) The biology and mechanism of action of nerve growth factor. Annu. Rev. Biochem. 51: 845-868.

Yu, M. W., N. W. Tolson, and G. Guroff (1980) Increased phosphorylation of specific nuclear proteins in superior cervical ganglia and PC1 2 cells in response to nerve growth factor. J. Biol. Chem. 255: 10481-10492.

Zanini, A., P. Angeletti, and R. Levi-Montalcini (1968) Immunochemical properties of the nerve growth factor. Proc. Natl. Acad. Sci. USA $61: 835-842$. 